\title{
Regulators of G protein Signaling (RGS) proteins (version 2020.5) in the IUPHAR/BPS Guide to Pharmacology Database
}

\author{
Katelin E. Ahlers-Dannen ${ }^{1}$, Mohammed Alqinyah², Christopher Bodle ${ }^{1}$, Josephine Bou Dagher ${ }^{2}$, Bandana \\ Chakravarti $^{1}$, Shreoshi P. Choudhuri ${ }^{3}$, Kirk M. Druey ${ }^{4}$, Rory A. Fisher ${ }^{1}$, Kyle J. Gerber ${ }^{5}$, John R. Hepler ${ }^{5}$, \\ Shelley B. Hooks ${ }^{2}$, Havish S. Kantheti ${ }^{3}$, Behirda Karaj ${ }^{6}$, Jae-Kyung Lee ${ }^{2}$, Zili Luo ${ }^{1}$, Kirill Martemyanov ${ }^{7}$, Luke D. \\ Mascarenhas $^{3}$, Carolina Montañez-Miranda ${ }^{8}$, Hoa Phan Thi Như , David L. Roman ${ }^{1}$, Vincent Shaw ${ }^{6}$, Benita \\ Sjögren ${ }^{9}$, Mackenzie M. Spicer ${ }^{1}$, Katherine E. Squires ${ }^{5}$, Laurie Sutton ${ }^{7}$, Menbere Wendimu ${ }^{2}$, Thomas M. \\ Wilkie $^{3}$, Keqiang $\mathrm{Xie}^{7}$ and Yalda Zolghadri ${ }^{3}$
}

1. University of lowa, USA

2. University of Georgia, USA

3. University of Texas Southwestern Medical Center, USA

4. National Institutes of Health, USA

5. Emory University, USA

6. Michigan State University, USA

7. Scripps Research Institute, USA

8. Emory University School of Medicine, USA

9. Purdue University, USA

\begin{abstract}
Regulator of G protein Signaling, or RGS, proteins serve an important regulatory role in signaling mediated by $G$ protein-coupled receptors (GPCRs). They all share a common RGS domain that directly interacts with active, GTP-bound $\mathrm{Ga}$ subunits of heterotrimeric $\mathrm{G}$ proteins. RGS proteins stabilize the transition state for GTP hydrolysis on $\mathrm{G} \alpha$ and thus induce a conformational change in the Ga subunit that accelerates GTP hydrolysis, thereby effectively turning off signaling cascades mediated by GPCRs. This GTPase accelerating protein (GAP) activity is the canonical mechanism of action for RGS proteins, although many also possess additional functions and domains. RGS proteins are divided into four families, R4, R7, R12 and RZ based on sequence homology, domain structure as well as specificity towards Ga subunits. For reviews on RGS proteins and their potential as therapeutic targets, see e.g. [183, 411, 446, 450, 451, 558, 566, 345, 9].
\end{abstract}

\section{Contents}

This is a citation summary for Regulators of G protein Signaling (RGS) proteins in the Guide to Pharmacology database (GtoPdb). It exists purely as an adjunct to the database to facilitate the recognition of citations to and from the database by citation analyzers. Readers will almost certainly want to visit the relevant sections of the database which are given here under database links.

GtoPdb is an expert-driven guide to pharmacological targets and the substances that act on them. GtoPdb is a reference work which is most usefully represented as an on-line database. As in any publication this work should be appropriately cited, and the papers it cites should also be recognized. This document provides a citation for the relevant parts of the database, and also provides a reference list for the research cited by those parts.

Please note that the database version for the citations given in GtoPdb are to the most recent preceding version in which the family or its subfamilies and targets were substantially changed. The links below are to the current version. If you need to consult the cited version, rather than the most recent version, please contact the GtoPdb curators.

\section{Database links}

Regulators of G protein Signaling (RGS) proteins

https://www.guidetopharmacology.org/GRAC/FamilyDisplayForward?familyld=891

RZ family

https://www.guidetopharmacology.org/GRAC/FamilyDisplayForward?familyld=892 


\section{Targets}

RGS17(regulator of G-protein signaling 17)

https://www.guidetopharmacology.org/GRAC/ObjectDisplayForward?objectld=2801

RGS19(regulator of G-protein signaling 19)

https://www.guidetopharmacology.org/GRAC/ObjectDisplayForward?objectld=2802

RGS20(regulator of G-protein signaling 20)

R4 family

https://www. guidetopharmacology.org/GRAC/ObjectDisplayForward?objectld=2803

https://www. guidetopharmacology.org/GRAC/FamilyDisplayForward?familyld=893

Targets

RGS1(regulator of G-protein signaling 1)

https://www.guidetopharmacology.org/GRAC/ObjectDisplayForward?objectld=2804 RGS2(regulator of G-protein signaling 2)

https://www.guidetopharmacology.org/GRAC/ObjectDisplayForward?objectld=2808

RGS3(regulator of G-protein signaling 3)

https://www.guidetopharmacology.org/GRAC/ObjectDisplayForward?objectld=2810

RGS4(regulator of G-protein signaling 4)

https://www.guidetopharmacology.org/GRAC/ObjectDisplayForward? objectld=2811

RGS5(regulator of G-protein signaling 5)

https://www.guidetopharmacology.org/GRAC/ObjectDisplayForward?objectld=2812

RGS8(regulator of G-protein signaling 8)

https://www.guidetopharmacology.org/GRAC/ObjectDisplayForward?objectld=2813

RGS13(regulator of G-protein signaling 13)

https://www.guidetopharmacology.org/GRAC/ObjectDisplayForward?objectld=2805

RGS16(regulator of G-protein signaling 16)

https://www. guidetopharmacology.org/GRAC/ObjectDisplayForward?objectld=2806

RGS18(regulator of G-protein signaling 18)

https://www. guidetopharmacology.org/GRAC/ObjectDisplayForward? objectld=2807

RGS21(regulator of G-protein signaling 21)

R7 family

https://www.guidetopharmacology.org/GRAC/ObjectDisplayForward?objectld=2809

https://www. guidetopharmacology.org/GRAC/FamilyDisplayForward?familyld=894

Targets

RGS6(regulator of G-protein signaling 6)

https://www.guidetopharmacology.org/GRAC/ObjectDisplayForward?objectld=2815

RGS7(regulator of G-protein signaling 7)

https://www.guidetopharmacology.org/GRAC/ObjectDisplayForward? objectld=2816

RGS9(regulator of G-protein signaling 9)

https://www.guidetopharmacology.org/GRAC/ObjectDisplayForward?objectld=2817

RGS11(regulator of G-protein signaling 11)

R12 family

https://www. guidetopharmacology.org/GRAC/ObjectDisplayForward?objectld=2814

https://www.guidetopharmacology.org/GRAC/FamilyDisplayForward?familyld=895

Targets

RGS10(regulator of G-protein signaling 10)

https://www.guidetopharmacology.org/GRAC/ObjectDisplayForward?objectld=2818

RGS12(regulator of G-protein signaling 12)

https://www.guidetopharmacology.org/GRAC/ObjectDisplayForward? objectld=2819

RGS14(regulator of G-protein signaling 14)

https://www.guidetopharmacology.org/GRAC/ObjectDisplayForward?objectld=2820

\section{References}

1. Abramow-Newerly M, Ming $H$ and Chidiac P. (2006) Modulation of subfamily B/R4 RGS protein function by 14-3-3 proteins. Cell. Signal. 18: 2209-22 [PMID:16839744]

2. Adams LD, Geary RL, Li J, Rossini A and Schwartz SM. (2006) Expression profiling identifies smooth muscle cell diversity within human intima and plaque fibrous cap: loss of RGS5 distinguishes the cap. Arterioscler. Thromb. Vasc. Biol. 26: 319-25 [PMID:16293795]

3. Aissani B, Wiener H and Zhang K. (2013) Multiple hits for the association of uterine fibroids on human chromosome 1q43. PLoS ONE 8: e58399 [PMID:23555580]

4. Ajit SK, Ramineni S, Edris W, Hunt RA, Hum WT, Hepler JR and Young KH. (2007) RGSZ1 interacts with protein kinase $\mathrm{C}$ interacting protein $\mathrm{PKCl}-1$ and modulates mu opioid receptor signaling. Cell. Signal. 19: 723-30 [PMID:17126529]

5. Ajit SK and Young KH. (2005) Analysis of chimeric RGS proteins in yeast for the functional evaluation of protein domains and their potential use in drug target validation. Cell Signal 17: 817-25 [PMID:15763424]

6. Allen Brain Atlas. RGS14

7. Almutairi F, Lee JK and Rada B. (2020) Regulator of G protein signaling 10: Structure, expression and 
functions in cellular physiology and diseases. Cell Signal 75: 109765 [PMID:32882407]

8. Alqinyah M, Almutairi F, Wendimu MY and Hooks SB. (2018) RGS10 Regulates the Expression of Cyclooxygenase-2 and Tumor Necrosis Factor Alpha through a G Protein-Independent Mechanism. Mol Pharmacol 94: 1103-1113 [PMID:30049816]

9. Alqinyah M and Hooks SB. (2018) Regulating the regulators: Epigenetic, transcriptional, and posttranslational regulation of RGS proteins. Cell. Signal. 42: 77-87 [PMID:29042285]

10. Alqinyah M, Maganti N, Ali MW, Yadav R, Gao M, Cacan E, Weng HR, Greer SF and Hooks SB. (2017) Regulator of G Protein Signaling 10 (Rgs10) Expression Is Transcriptionally Silenced in Activated Microglia by Histone Deacetylase Activity. Mol Pharmacol 91: 197-207 [PMID:28031332]

11. Altman MK, Alshamrani AA, Jia W, Nguyen HT, Fambrough JM, Tran SK, Patel MB, Hoseinzadeh P, Beedle AM and Murph MM. (2015) Suppression of the GTPase-activating protein RGS10 increases RhebGTP and mTOR signaling in ovarian cancer cells. Cancer Lett 369: 175-83 [PMID:26319900]

12. Altman MK, Nguyen DT, Patel SB, Fambrough JM, Beedle AM, Hardman WJ and Murph MM. (2012) Regulator of G-Protein Signaling 5 Reduces HeyA8 Ovarian Cancer Cell Proliferation and Extends Survival in a Murine Tumor Model. Biochem Res Int 2012: 518437 [PMID:22792465]

13. Amundsen SS, Rundberg J, Adamovic S, Gudjónsdóttir AH, Ascher H, Ek J, Nilsson S, Lie BA, Naluai AT and Sollid LM. (2010) Four novel coeliac disease regions replicated in an association study of a SwedishNorwegian family cohort. Genes Immun. 11: 79-86 [PMID:19693089]

14. Anderson A, Masuho I, Marron Fernandez de Velasco E, Nakano A, Birnbaumer L, Martemyanov KA and Wickman K. (2020) GPCR-dependent biasing of GIRK channel signaling dynamics by RGS6 in mouse sinoatrial nodal cells. Proc. Natt. Acad. Sci. U.S.A. 117: 14522-14531 [PMID:32513692]

15. Anderson GR, Cao Y, Davidson S, Truong HV, Pravetoni M, Thomas MJ, Wickman K, Giesler Jr GJ and Martemyanov KA. (2010) R7BP complexes with RGS9-2 and RGS7 in the striatum differentially control motor learning and locomotor responses to cocaine. Neuropsychopharmacology 35: 1040-50 [PMID:20043004]

16. Anderson GR, Posokhova E and Martemyanov KA. (2009) The R7 RGS protein family: multi-subunit regulators of neuronal G protein signaling. Cell Biochem. Biophys. 54: 33-46 [PMID:19521673]

17. Anger T, El-Chafchak J, Habib A, Stumpf C, Weyand M, Daniel WG, Hombach V, Hoeher M and Garlichs CD. (2008) Statins stimulate RGS-regulated ERK 1/2 activation in human calcified and stenotic aortic valves. Exp. Mol. Pathol. 85: 101-11 [PMID:18671964]

18. Appleton CT, James CG and Beier F. (2006) Regulator of G-protein signaling (RGS) proteins differentially control chondrocyte differentiation. J. Cell. Physiol. 207: 735-45 [PMID:16489565]

19. Arnold C, Feldner A, Pfisterer L, Hödebeck M, Troidl K, Genové G, Wieland T, Hecker M and Korff T. (2014) RGS5 promotes arterial growth during arteriogenesis. EMBO Mol Med 6: 1075-89 [PMID:24972930]

20. Balenga NA, Jester W, Jiang M, Panettieri Jr RA and Druey KM. (2014) Loss of regulator of G protein signaling 5 promotes airway hyperresponsiveness in the absence of allergic inflammation. J. Allergy Clin. Immunol. 134: 451-9 [PMID:24666695]

21. Bansal G, DiVietro JA, Kuehn HS, Rao S, Nocka KH, Gilfillan AM and Druey KM. (2008) RGS13 controls g protein-coupled receptor-evoked responses of human mast cells. J. Immunol. 181: 7882-90 [PMID:19017978]

22. Bansal G, Xie Z, Rao S, Nocka KH and Druey KM. (2008) Suppression of immunoglobulin E-mediated allergic responses by regulator of $\mathrm{G}$ protein signaling 13. Nat. Immunol. 9: 73-80 [PMID:18026105]

23. Barker SA, Wang J, Sierra DA and Ross EM. (2001) RGSZ1 and Ret RGS: two of several splice variants from the gene RGS20. Genomics 78: 223-9 [PMID:11735229]

24. Barrett JC, Clayton DG, Concannon P, Akolkar B, Cooper JD, Erlich HA, Julier C, Morahan G, Nerup J and Nierras $C$ et al.. (2009) Genome-wide association study and meta-analysis find that over 40 loci affect risk of type 1 diabetes. Nat. Genet. 41: 703-7 [PMID:19430480]

25. Bartel M, Schäfer A, Stevers LM and Ottmann C. (2014) Small molecules, peptides and natural products: getting a grip on 14-3-3 protein-protein modulation. Future Med Chem 6: 903-21 [PMID:24962282]

26. Barzilay E, Yung Y, Shapira L, Haas J, Ophir L, Yerushalmi GM, Maman E and Hourvitz A. (2014) Differential expression of poliovirus receptor, regulator of G-protein signaling 11 and erythrocyte protein band 4.1-like 3 in human granulosa cells during follicular growth and maturation. Gynecol. Endocrinol. 30: 660-3 [PMID:24828608]

27. Beadling C, Druey KM, Richter G, Kehrl JH and Smith KA. (1999) Regulators of G protein signaling exhibit distinct patterns of gene expression and target $\mathrm{G}$ protein specificity in human lymphocytes. J. Immunol. 162: 2677-82 [PMID:10072511]

28. BellBrook Labs. RGScreen ${ }^{\mathrm{TM}}$ Service.

29. Benians A, Nobles M, Hosny S and Tinker A. (2005) Regulators of G-protein signaling form a quaternary complex with the agonist, receptor, and G-protein. A novel explanation for the acceleration of signaling activation kinetics. J. Biol. Chem. 280: 13383-94 [PMID:15677457]

30. Benians A, Nobles M and Tinker A. (2004) Participation of RGS8 in the ternary complex of agonist, receptor and G-protein. Biochem. Soc. Trans. 32: 1045-7 [PMID:15506959]

31. Benzing T, Köttgen M, Johnson M, Schermer B, Zentgraf H, Walz G and Kim E. (2002) Interaction of 14-33 protein with regulator of $\mathrm{G}$ protein signaling 7 is dynamically regulated by tumor necrosis factor-alpha. $J$. Biol. Chem. 277: 32954-62 [PMID:12077120]

32. Benzing T, Yaffe MB, Arnould T, Sellin L, Schermer B, Schilling B, Schreiber R, Kunzelmann K, Leparc GG and Kim E et al.. (2000) 14-3-3 interacts with regulator of G protein signaling proteins and modulates 
their activity. J. Biol. Chem. 275: 28167-72 [PMID:10862767]

33. Berger M, Bergers G, Arnold B, Hämmerling GJ and Ganss R. (2005) Regulator of G-protein signaling-5 induction in pericytes coincides with active vessel remodeling during neovascularization. Blood 105: 1094101 [PMID:15459006]

34. Berman DM, Kozasa T and Gilman AG. (1996) The GTPase-activating protein RGS4 stabilizes the transition state for nucleotide hydrolysis. J. Biol. Chem. 271: 27209-12 [PMID:8910288]

35. Berman DM, Wang Y, Liu Z, Dong Q, Burke LA, Liotta LA, Fisher R and Wu X. (2004) A functional polymorphism in RGS6 modulates the risk of bladder cancer. Cancer Res. 64: 6820-6 [PMID:15375002]

36. Berman DM, Wilkie TM and Gilman AG. (1996) GAIP and RGS4 are GTPase-activating proteins for the Gi subfamily of $\mathrm{G}$ protein alpha subunits. Cell 86: 445-52 [PMID:8756726]

37. Bernstein LS, Grillo AA, Loranger SS and Linder ME. (2000) RGS4 binds to membranes through an amphipathic alpha -helix. J. Biol. Chem. 275: 18520-6 [PMID:10764749]

38. Bernstein LS, Ramineni S, Hague C, Cladman W, Chidiac P, Levey Al and Hepler JR. (2004) RGS2 binds directly and selectively to the M1 muscarinic acetylcholine receptor third intracellular loop to modulate Gq/11alpha signaling. J. Biol. Chem. 279: 21248-56 [PMID:14976183]

39. Berthebaud M, Rivière C, Jarrier P, Foudi A, Zhang Y, Compagno D, Galy A, Vainchenker W and Louache F. (2005) RGS16 is a negative regulator of SDF-1-CXCR4 signaling in megakaryocytes. Blood 106: 29628 [PMID:15998835]

40. Bifsha P, Yang J, Fisher RA and Drouin J. (2014) Rgs6 is required for adult maintenance of dopaminergic neurons in the ventral substantia nigra. PLoS Genet. 10: e1004863 [PMID:25501001]

41. BioGRID ${ }^{3.4}$. PLSCR1.

42. Blazer LL, Roman DL, Chung A, Larsen MJ, Greedy BM, Husbands SM and Neubig RR. (2010) Reversible, allosteric small-molecule inhibitors of regulator of $\mathrm{G}$ protein signaling proteins. Mol. Pharmacol. 78: 524-33 [PMID:20571077]

43. Blazer LL, Zhang H, Casey EM, Husbands SM and Neubig RR. (2011) A nanomolar-potency small molecule inhibitor of regulator of G-protein signaling proteins. Biochemistry 50: 3181-92 [PMID:21329361]

44. Blundell J, Hoang CV, Potts B, Gold SJ and Powell CM. (2008) Motor coordination deficits in mice lacking RGS9. Brain Res. 1190: 78-85 [PMID:18073128]

45. Bodenstein J, Sunahara RK and Neubig RR. (2007) N-terminal residues control proteasomal degradation of RGS2, RGS4, and RGS5 in human embryonic kidney 293 cells. Mol. Pharmacol. 71: 1040-50 [PMID:17220356]

46. Bondjers C, Kalén M, Hellström M, Scheidl SJ, Abramsson A, Renner O, Lindahl P, Cho H, Kehrl J and Betsholtz C. (2003) Transcription profiling of platelet-derived growth factor-B-deficient mouse embryos identifies RGS5 as a novel marker for pericytes and vascular smooth muscle cells. Am. J. Pathol. 162: 7219 [PMID:12598306]

47. Bonsi P, Ponterio G, Vanni V, Tassone A, Sciamanna G, Migliarini S, Martella G, Meringolo M, Dehay B and Doudnikoff $E$ et al.. (2019) RGS9-2 rescues dopamine D2 receptor levels and signaling inDYT1 dystonia mouse models. EMBO Mol Med 11: e9283 [PMID:30552094]

48. Bosch DE, Zielinski T, Lowery RG and Siderovski DP. (2012) Evaluating modulators of "Regulator of Gprotein Signaling" (RGS) proteins. Curr Protoc Pharmaco/Chapter 2: Unit2.8 [PMID:22382998]

49. Bouhamdan M, Yan HD, Yan XH, Bannon MJ and Andrade R. (2006) Brain-specific regulator of G-protein signaling 9-2 selectively interacts with alpha-actinin-2 to regulate calcium-dependent inactivation of NMDA receptors. J. Neurosci. 26: 2522-30 [PMID:16510730]

50. Bowman EP, Campbell JJ, Druey KM, Scheschonka A, Kehrl JH and Butcher EC. (1998) Regulation of chemotactic and proadhesive responses to chemoattractant receptors by RGS (regulator of G-protein signaling) family members. J. Biol. Chem. 273: 28040-8 [PMID:9774420]

51. Bradfield JP, Qu HQ, Wang K, Zhang H, Sleiman PM, Kim CE, Mentch FD, Qiu H, Glessner JT and Thomas KA et al.. (2011) A genome-wide meta-analysis of six type 1 diabetes cohorts identifies multiple associated loci. PLoS Genet. 7: e1002293 [PMID:21980299]

52. Branch MR and Hepler JR. (2017) Endogenous RGS14 is a cytoplasmic-nuclear shuttling protein that localizes to juxtanuclear membranes and chromatin-rich regions of the nucleus. PLoS One 12: e0184497 [PMID:28934222]

53. Brown NE, Blumer JB and Hepler JR. (2015) Bioluminescence resonance energy transfer to detect protein-protein interactions in live cells. Methods Mol. Biol. 1278: 457-65 [PMID:25859969]

54. Brown NE, Goswami D, Branch MR, Ramineni S, Ortlund EA, Griffin PR and Hepler JR. (2015) Integration of $\mathrm{G}$ protein $\alpha(\mathrm{G} \alpha)$ signaling by the regulator of $\mathrm{G}$ protein signaling 14 (RGS14). J. Biol. Chem. 290: 903749 [PMID:25666614]

55. Brown NE, Lambert NA and Hepler JR. (2016) RGS14 regulates the lifetime of G-GTP signaling but does not prolong G $\beta \gamma$ signaling following receptor activation in live cells. Pharmacol Res Perspect 4: e00249 [PMID:27713821]

56. Buckbinder L, Velasco-Miguel S, Chen Y, Xu N, Talbott R, Gelbert L, Gao J, Seizinger BR, Gutkind JS and Kley N. (1997) The p53 tumor suppressor targets a novel regulator of G protein signaling. Proc. Natl. Acad. Sci. U.S.A. 94: 7868-72 [PMID:9223279]

57. Burgon PG, Lee WL, Nixon AB, Peralta EG and Casey PJ. (2001) Phosphorylation and nuclear translocation of a regulator of G protein signaling (RGS10). J Biol Chem 276: 32828-34 [PMID:11443111]

58. Caballero-Franco $C$ and Kissler S. (2016) The autoimmunity-associated gene RGS1 affects the frequency of T follicular helper cells. Genes Immun. 17: 228-38 [PMID:27029527] 
59. Cabrera JL, de Freitas F, Satpaev DK and Slepak VZ. (1998) Identification of the Gbeta5-RGS7 protein complex in the retina. Biochem. Biophys. Res. Commun. 249: 898-902 [PMID:9731233]

60. Cabrera-Vera TM, Hernandez S, Earls LR, Medkova M, Sundgren-Andersson AK, Surmeier DJ and Hamm HE. (2004) RGS9-2 modulates D2 dopamine receptor-mediated Ca2+ channel inhibition in rat striatal cholinergic interneurons. Proc. Natl. Acad. Sci. U.S.A. 101: 16339-44 [PMID:15534226]

61. Cacan E, Ali MW, Boyd NH, Hooks SB and Greer SF. (2014) Inhibition of HDAC1 and DNMT1 modulate RGS10 expression and decrease ovarian cancer chemoresistance. PLoS ONE 9: e87455 [PMID:24475290]

62. Cahir-McFarland ED, Carter K, Rosenwald A, Giltnane JM, Henrickson SE, Staudt LM and Kieff E. (2004) Role of NF-kappa B in cell survival and transcription of latent membrane protein 1-expressing or EpsteinBarr virus latency III-infected cells. J. Virol. 78: 4108-19 [PMID:15047827]

63. Calò LA, Pagnin E, Davis PA, Sartori M, Ceolotto G, Pessina AC and Semplicini A. (2004) Increased expression of regulator of G protein signaling-2 (RGS-2) in Bartter's/Gitelman's syndrome. A role in the control of vascular tone and implication for hypertension. J. Clin. Endocrinol. Metab. 89: 4153-7 [PMID:15292363]

64. Cao Y, Masuho I, Okawa H, Xie K, Asami J, Kammermeier PJ, Maddox DM, Furukawa T, Inoue T and Sampath AP et al.. (2009) Retina-specific GTPase accelerator RGS11/G beta 5S/R9AP is a constitutive heterotrimer selectively targeted to mGluR6 in ON-bipolar neurons. J. Neurosci. 29: 9301-13 [PMID:19625520]

65. Cao Y, Pahlberg J, Sarria I, Kamasawa N, Sampath AP and Martemyanov KA. (2012) Regulators of G protein signaling RGS7 and RGS11 determine the onset of the light response in ON bipolar neurons. Proc. Natl. Acad. Sci. U.S.A. 109: 7905-10 [PMID:22547806]

66. Carper MB, Denvir J, Boskovic G, Primerano DA and Claudio PP. (2014) RGS16, a novel p53 and pRb cross-talk candidate inhibits migration and invasion of pancreatic cancer cells. Genes Cancer 5: 420-35 [PMID:25568667]

67. Celver J, Sharma M and Kovoor A. (2012) D(2)-Dopamine receptors target regulator of G protein signaling 9-2 to detergent-resistant membrane fractions. J. Neurochem. 120: 56-69 [PMID:22035199]

68. Chakravarti B, Yang J, Ahlers-Dannen KE, Luo Z, Flaherty HA, Meyerholz DK, Anderson ME and Fisher RA. (2017) Essentiality of Regulator of G Protein Signaling 6 and Oxidized $\mathrm{Ca}^{2+} /$ Calmodulin-Dependent Protein Kinase II in Notch Signaling and Cardiovascular Development. J Am Heart Assoc 6: [PMID:29079565]

69. Charlton JJ, Allen PB, Psifogeorgou K, Chakravarty S, Gomes I, Neve RL, Devi LA, Greengard P, Nestler EJ and Zachariou V. (2008) Multiple actions of spinophilin regulate mu opioid receptor function. Neuron 58: 238-47 [PMID:18439408]

70. Chatterjee TK, Eapen A, Kanis AB and Fisher RA. (1997) Genomic organization, 5'-flanking region, and chromosomal localization of the human RGS3 gene. Genomics 45: 429-33 [PMID:9344672]

71. Chatterjee TK, Eapen AK and Fisher RA. (1997) A truncated form of RGS3 negatively regulates G proteincoupled receptor stimulation of adenylyl cyclase and phosphoinositide phospholipase C. J. Biol. Chem. 272: 15481-7 [PMID:9182581]

72. Chatterjee TK and Fisher RA. (2000) Novel alternative splicing and nuclear localization of human RGS12 gene products. J. Biol. Chem. 275: 29660-71 [PMID:10869340]

73. Chatterjee TK, Liu Z and Fisher RA. (2003) Human RGS6 gene structure, complex alternative splicing, and role of $\mathrm{N}$ terminus and $\mathrm{G}$ protein gamma-subunit-like (GGL) domain in subcellular localization of RGS6 splice variants. J. Biol. Chem. 278: 30261-71 [PMID:12761221]

74. Chen B, Siderovski DP, Neubig RR, Lawson MA and Trejo J. (2014) Regulation of protease-activated receptor 1 signaling by the adaptor protein complex 2 and $\mathrm{R} 4$ subfamily of regulator of $\mathrm{G}$ protein signaling proteins. J. Biol. Chem. 289: 1580-91 [PMID:24297163]

75. Chen C, Zheng B, Han J and Lin SC. (1997) Characterization of a novel mammalian RGS protein that binds to Galpha proteins and inhibits pheromone signaling in yeast. J. Biol. Chem. 272: 8679-85 [PMID:9079700]

76. Chen CK, Burns ME, He W, Wensel TG, Baylor DA and Simon MI. (2000) Slowed recovery of rod photoresponse in mice lacking the GTPase accelerating protein RGS9-1. Nature 403: 557-60 [PMID:10676965]

77. Chen CK, Wieland T and Simon MI. (1996) RGS-r, a retinal specific RGS protein, binds an intermediate conformation of transducin and enhances recycling. Proc. Natl. Acad. Sci. U.S.A. 93: 12885-9 [PMID:8917514]

78. Chen G. (2017) A Genome-Wise Association Study of A Quantitative Alcoholism Trait Using A Full Genetic Model Identifies Significant SNP Heritability From Dominance And Epistatic Interactions European Neuropsychopharmacology 27: S363

79. Chen X, Dunham C, Kendler S, Wang X, O'Neill FA, Walsh D and Kendler KS. (2004) Regulator of Gprotein signaling 4 (RGS4) gene is associated with schizophrenia in Irish high density families. Am. J. Med. Genet. B Neuropsychiatr. Genet. 129B: 23-6 [PMID:15274033]

80. Cheng JY, Luu CD, Yong VH, Mathur R, Aung T and Vithana EN. (2007) Bradyopsia in an Asian man. Arch. Ophthalmol. 125: 1138-40 [PMID:17698770]

81. Cheng WL, Wang PX, Wang T, Zhang Y, Du C, Li H and Ji Y. (2015) Regulator of G-protein signalling 5 protects against atherosclerosis in apolipoprotein E-deficient mice. Br. J. Pharmacol. 172: 5676-89 [PMID:25363362] 
82. Cho H, Harrison K, Schwartz O and Kehrl JH. (2003) The aorta and heart differentially express RGS (regulators of G-protein signalling) proteins that selectively regulate sphingosine 1-phosphate, angiotensin II and endothelin-1 signalling. Biochem. J. 371: 973-80 [PMID:12564955]

83. Cho H, Kim DU and Kehrl JH. (2005) RGS14 is a centrosomal and nuclear cytoplasmic shuttling protein that traffics to promyelocytic leukemia nuclear bodies following heat shock. J. Biol. Chem. 280: 805-14 [PMID:15520006]

84. Cho H, Kozasa T, Bondjers C, Betsholtz C and Kehrl JH. (2003) Pericyte-specific expression of Rgs5: implications for PDGF and EDG receptor signaling during vascular maturation. FASEB J. 17: 440-2 [PMID:12514120]

85. Cho H, Kozasa T, Takekoshi K, De Gunzburg J and Kehrl JH. (2000) RGS14, a GTPase-activating protein for Gialpha, attenuates Gialpha- and G13alpha-mediated signaling pathways. Mol. Pharmacol. 58: 569-76 [PMID:10953050]

86. Cho H, Park C, Hwang IY, Han SB, Schimel D, Despres D and Kehrl JH. (2008) Rgs5 targeting leads to chronic low blood pressure and a lean body habitus. Mol. Cell. Biol. 28: 2590-7 [PMID:18268011]

87. Chograni M, Alkuraya FS, Maazoul F, Lariani I and Chaabouni-Bouhamed H. (2015) RGS6: a novel gene associated with congenital cataract, mental retardation, and microcephaly in a Tunisian family. Invest. Ophthalmol. Vis. Sci. 56: 1261-6 [PMID:25525169]

88. Chograni M, Alkuraya FS, Ourteni I, Maazoul F, Lariani I and Chaabouni HB. (2015) Autosomal recessive congenital cataract, intellectual disability phenotype linked to STX3 in a consanguineous Tunisian family. Clin. Genet. 88: 283-7 [PMID:25358429]

89. Chowdari KV, Mirnics K, Semwal P, Wood J, Lawrence E, Bhatia T, Deshpande SN, B K T, Ferrell RE and Middleton FA et al.. (2002) Association and linkage analyses of RGS4 polymorphisms in schizophrenia. Hum. Mol. Genet. 11: 1373-80 [PMID:12023979]

90. Chuang HH, Yu M, Jan YN and Jan LY. (1998) Evidence that the nucleotide exchange and hydrolysis cycle of $\mathrm{G}$ proteins causes acute desensitization of G-protein gated inward rectifier K+ channels. Proc. Natl. Acad. Sci. U.S.A. 95: 11727-32 [PMID:9751733]

91. Cifelli C, Rose RA, Zhang H, Voigtlaender-Bolz J, Bolz SS, Backx PH and Heximer SP. (2008) RGS4 regulates parasympathetic signaling and heart rate control in the sinoatrial node. Circ. Res. 103: 527-35 [PMID:18658048]

92. Cohen SP, Buckley BK, Kosloff M, Garland AL, Bosch DE, Cheng Jr G, Radhakrishna H, Brown MD, Willard FS and Arshavsky VY et al.. (2012) Regulator of G-protein signaling-21 (RGS21) is an inhibitor of bitter gustatory signaling found in lingual and airway epithelia. J. Biol. Chem. 287: 41706-19 [PMID:23095746]

93. Cowan CW, Fariss RN, Sokal I, Palczewski K and Wensel TG. (1998) High expression levels in cones of RGS9, the predominant GTPase accelerating protein of rods. Proc. Natl. Acad. Sci. U.S.A. 95: 5351-6 [PMID:9560279]

94. Cowan CW, Wensel TG and Arshavsky VY. (2000) Enzymology of GTPase acceleration in phototransduction. Meth. Enzymol. 315: 524-38 [PMID:10736724]

95. Dai J, Gu J, Lu C, Lin J, Stewart D, Chang D, Roth JA and Wu X. (2011) Genetic variations in the regulator of G-protein signaling genes are associated with survival in late-stage non-small cell lung cancer. PLoS ONE 6: e21120 [PMID:21698121]

96. Dansithong W, Paul S, Figueroa KP, Rinehart MD, Wiest S, Pflieger LT, Scoles DR and Pulst SM. (2015) Ataxin-2 regulates RGS8 translation in a new BAC-SCA2 transgenic mouse model. PLoS Genet. 11: e1005182 [PMID:25902068]

97. Davidsson J, Andersson A, Paulsson K, Heidenblad M, Isaksson M, Borg A, Heldrup J, Behrendtz M, Panagopoulos I and Fioretos T et al.. (2007) Tiling resolution array comparative genomic hybridization, expression and methylation analyses of dup(1q) in Burkitt lymphomas and pediatric high hyperdiploid acute lymphoblastic leukemias reveal clustered near-centromeric breakpoints and overexpression of genes in 1q22-32.3. Hum. Mol. Genet. 16: 2215-25 [PMID:17613536]

98. de Alba E, De Vries L, Farquhar MG and Tjandra N. (1999) Solution structure of human GAIP (Galpha interacting protein): a regulator of G protein signaling. J. Mol. Biol. 291: 927-39 [PMID:10452897]

99. de Souza EE, Hehnly H, Perez AM, Meirelles GV, Smetana JH, Doxsey S and Kobarg J. (2015) Human Nek7-interactor RGS2 is required for mitotic spindle organization. Cell Cycle 14: 656-67 [PMID:25664600]

100. DeHelian D, Gupta S, Wu J, Thorsheim C, Estevez B, Cooper M, Litts K, Lee-Sundlov MM, Hoffmeister KM and Poncz M et al.. (2020) RGS10 and RGS18 differentially limit platelet activation, promote platelet production, and prolong platelet survival. Blood 136: 1773-1782 [PMID:32542378]

101. Delesque-Touchard N, Pendaries C, Volle-Challier C, Millet L, Salel V, Hervé C, Pflieger AM, BerthouSoulie L, Prades C and Sorg T et al.. (2014) Regulator of G-protein signaling 18 controls both platelet generation and function. PLOS ONE 9: e113215 [PMID:25405900]

102. Denecke B, Meyerdierks A and Böttger EC. (1999) RGS1 is expressed in monocytes and acts as a GTPase-activating protein for G-protein-coupled chemoattractant receptors. J. Biol. Chem. 274: 26860-8 [PMID:10480894]

103. Derrien A and Druey KM. (2001) RGS16 function is regulated by epidermal growth factor receptormediated tyrosine phosphorylation. J. Biol. Chem. 276: 48532-8 [PMID:11602604]

104. Desai BB, Albright JW and Albright JF. (1987) Cooperative action of complement component C3 and phagocytic effector cells in innate murine resistance to Trypanosoma lewisi. Infect. Immun. 55: 358-63 [PMID:3026965]

105. Dhingra A, Faurobert E, Dascal N, Sterling P and Vardi N. (2004) A retinal-specific regulator of G-protein 
signaling interacts with Galpha(o) and accelerates an expressed metabotropic glutamate receptor 6 cascade. J Neurosci 24: 5684-93 [PMID:15215290]

106. Ding $L$ and Hegde AN. (2009) Expression of RGS4 splice variants in dorsolateral prefrontal cortex of schizophrenic and bipolar disorder patients. Biol. Psychiatry 65: 541-5 [PMID:19041089]

107. Doi M, Ishida A, Miyake A, Sato M, Komatsu R, Yamazaki F, Kimura I, Tsuchiya S, Kori H and Seo Ket al.. (2011) Circadian regulation of intracellular G-protein signalling mediates intercellular synchrony and rhythmicity in the suprachiasmatic nucleus. Nat Commun 2: 327 [PMID:21610730]

108. Doupnik CA, Xu T and Shinaman JM. (2001) Profile of RGS expression in single rat atrial myocytes. Biochim. Biophys. Acta 1522: 97-107 [PMID:11750060]

109. Dowal L, Elliott J, Popov S, Wilkie TM and Scarlata S. (2001) Determination of the contact energies between a regulator of $\mathrm{G}$ protein signaling and $\mathrm{G}$ protein subunits and phospholipase $\mathrm{C}$ beta 1. Biochemistry 40: 414-21 [PMID:11148035]

110. Drenan RM, Doupnik CA, Boyle MP, Muglia LJ, Huettner JE, Linder ME and Blumer KJ. (2005) Palmitoylation regulates plasma membrane-nuclear shuttling of R7BP, a novel membrane anchor for the RGS7 family. J. Cell Biol. 169: 623-33 [PMID:15897264]

111. Druey KM, Blumer KJ, Kang VH and Kehrl JH. (1996) Inhibition of G-protein-mediated MAP kinase activation by a new mammalian gene family. Nature 379: 742-6 [PMID:8602223]

112. Dulin NO, Pratt P, Tiruppathi C, Niu J, Voyno-Yasenetskaya T and Dunn MJ. (2000) Regulator of G protein signaling RGS3T is localized to the nucleus and induces apoptosis. J. Biol. Chem. 275: 21317-23 [PMID:10749886]

113. Dulin NO, Sorokin A, Reed E, Elliott S, Kehrl JH and Dunn MJ. (1999) RGS3 inhibits G protein-mediated signaling via translocation to the membrane and binding to Galpha11. Mol. Cell. Biol. 19: 714-23 [PMID:9858594]

114. Dusonchet J, Li H, Guillily M, Liu M, Stafa K, Derada Troletti C, Boon JY, Saha S, Glauser L and Mamais A et al.. (2014) A Parkinson's disease gene regulatory network identifies the signaling protein RGS2 as a modulator of LRRK2 activity and neuronal toxicity. Hum. Mol. Genet. 23: 4887-905 [PMID:24794857]

115. EMBL-EBI Expression Atlas. RGS14 regulator of G-protein signaling 14

116. Evans PR, Gerber KJ, Dammer EB, Duong DM, Goswami D, Lustberg DJ, Zou J, Yang JJ, Dudek SM and Griffin PR et al.. (2018) Interactome Analysis Reveals Regulator of G Protein Signaling 14 (RGS14) is a Novel Calcium/Calmodulin $\left(\mathrm{Ca}^{2+} / \mathrm{CaM}\right)$ and CaM Kinase II (CaMKII) Binding Partner. J Proteome Res 17: 1700-1711 [PMID:29518331]

117. Evans PR, Lee SE, Smith Y and Hepler JR. (2014) Postnatal developmental expression of regulator of G protein signaling 14 (RGS14) in the mouse brain. J. Comp. Neurol. 522: 186-203 [PMID:23817783]

118. Evans PR, Parra-Bueno P, Smirnov MS, Lustberg DJ, Dudek SM, Hepler JR and Yasuda R. (2018) RGS14 Restricts Plasticity in Hippocampal CA2 by Limiting Postsynaptic Calcium Signaling. eNeuro 5: [PMID:29911178]

119. Ewing RM, Chu P, Elisma F, Li H, Taylor P, Climie S, McBroom-Cerajewski L, Robinson MD, O'Connor L and Li M et al.. (2007) Large-scale mapping of human protein-protein interactions by mass spectrometry. Mol. Syst. Biol. 3: 89 [PMID:17353931]

120. Fajardo-Serrano A, Wydeven N, Young D, Watanabe M, Shigemoto R, Martemyanov KA, Wickman K and Luján R. (2013) Association of Rgs7/G $\beta 5$ complexes with Girk channels and GABAB receptors in hippocampal CA1 pyramidal neurons. Hippocampus 23: 1231-45 [PMID:23804514]

121. Fang X, Chung J, Olsen E, Snider I, Earls RH, Jeon J, Park HJ and Lee JK. (2019) Depletion of regulatorof-G-protein signaling-10 in mice exaggerates high-fat diet-induced insulin resistance and inflammation, and this effect is mitigated by dietary green tea extract. Nutr Res 70: 50-59 [PMID:30032988]

122. Faruque MU, Chen G, Doumatey A, Huang H, Zhou J, Dunston GM, Rotimi CN and Adeyemo AA. (2011) Association of ATP1B1, RGS5 and SELE polymorphisms with hypertension and blood pressure in AfricanAmericans. J. Hypertens. 29: 1906-12 [PMID:21881522]

123. Faurobert $E$ and Hurley JB. (1997) The core domain of a new retina specific RGS protein stimulates the GTPase activity of transducin in vitro. Proc. Natl. Acad. Sci. U.S.A. 94: 2945-50 [PMID:9096326]

124. Ferkey DM, Hyde R, Haspel G, Dionne HM, Hess HA, Suzuki H, Schafer WR, Koelle MR and Hart AC. (2007) C. elegans G protein regulator RGS-3 controls sensitivity to sensory stimuli. Neuron 53: $39-52$ [PMID:17196529]

125. Fischer T, De Vries L, Meerloo T and Farquhar MG. (2003) Promotion of G alpha i3 subunit downregulation by GIPN, a putative E3 ubiquitin ligase that interacts with RGS-GAIP. Proc. Natl. Acad. Sci. U.S.A. 100: 8270-5 [PMID:12826607]

126. Franić S, Groen-Blokhuis MM, Dolan CV, Kattenberg MV, Pool R, Xiao X, Scheet PA, Ehli EA, Davies GE and van der Sluis S et al.. (2015) Intelligence: shared genetic basis between Mendelian disorders and a polygenic trait. Eur. J. Hum. Genet. 23: 1378-83 [PMID:25712083]

127. Friedman PA, Mamonova T, Magyar CE, Squires KE, Sneddon WB, Emlet DR and Hepler JR. (2019) Genetic variants disrupt human RGS14 binding to NHERF1 and regulation of NPT2A-mediated phosphate transport bioRxiv

128. Fujii S, Yamazoe G, Itoh M, Kubo Y and Saitoh O. (2008) Spinophilin inhibits the binding of RGS8 to M1mAChR but enhances the regulatory function of RGS8. Biochem. Biophys. Res. Commun. 377: 200-4 [PMID:18834863]

129. Gagnon AW, Murray DL and Leadley RJ. (2002) Cloning and characterization of a novel regulator of $G$ protein signalling in human platelets. Cell. Signal. 14: 595-606 [PMID:11955952] 
130. Gao Y, Shen M, Gonzalez JC, Dong Q, Kannan S, Hoang JT, Eisinger BE, Pandey J, Javadi S and Chang $Q$ et al.. (2020) RGS6 Mediates Effects of Voluntary Running on Adult Hippocampal Neurogenesis.Cell Rep 32: 107997 [PMID:32755589]

131. García-Bernal D, Dios-Esponera A, Sotillo-Mallo E, García-Verdugo R, Arellano-Sánchez N and Teixidó J. (2011) RGS10 restricts upregulation by chemokines of T cell adhesion mediated by $\alpha 4 \beta 1$ and $\alpha \mathrm{L} \beta 2$ integrins. J. Immunol. 187: 1264-72 [PMID:21705617]

132. Garzón J, López-Fando A and Sánchez-Blázquez P. (2003) The R7 subfamily of RGS proteins assists tachyphylaxis and acute tolerance at mu-opioid receptors. Neuropsychopharmacology 28: 1983-90 [PMID:12902995]

133. Garzón J, Rodríguez-Díaz M, López-Fando A and Sánchez-Blázquez P. (2001) RGS9 proteins facilitate acute tolerance to mu-opioid effects. Eur. J. Neurosci. 13: 801-11 [PMID:11207815]

134. Garzón J, Rodríguez-Muñoz M, de la Torre-Madrid E and Sánchez-Blázquez P. (2005) Effector antagonism by the regulators of $\mathrm{G}$ protein signalling (RGS) proteins causes desensitization of mu-opioid receptors in the CNS. Psychopharmacology (Berl.) 180: 1-11 [PMID:15830230]

135. Garzón J, Rodríguez-Muñoz M, López-Fando A, García-España A and Sánchez-Blázquez P. (2004) RGSZ1 and GAIP regulate mu- but not delta-opioid receptors in mouse CNS: role in tachyphylaxis and acute tolerance. Neuropsychopharmacology 29: 1091-104 [PMID:14997173]

136. Garzón J, Rodríguez-Muñoz M, López-Fando A and Sánchez-Blázquez P. (2005) Activation of mu-opioid receptors transfers control of Galpha subunits to the regulator of G-protein signaling RGS9-2: role in receptor desensitization. J. Biol. Chem. 280: 8951-60 [PMID:15632124]

137. Gaspari S, Papachatzaki MM, Koo JW, Carr FB, Tsimpanouli ME, Stergiou E, Bagot RC, Ferguson D, Mouzon E and Chakravarty S et al.. (2014) Nucleus accumbens-specific interventions in RGS9-2 activity modulate responses to morphine. Neuropsychopharmacology 39: 1968-77 [PMID:24561386]

138. Gegenbauer K, Elia G, Blanco-Fernandez A and Smolenski A. (2012) Regulator of G-protein signaling 18 integrates activating and inhibitory signaling in platelets. Blood 119: 3799-807 [PMID:22234696]

139. Gegenbauer K, Nagy Z and Smolenski A. (2013) Cyclic nucleotide dependent dephosphorylation of regulator of G-protein signaling 18 in human platelets. PLoS ONE 8: e80251 [PMID:24244663]

140. Georgoussi Z, Leontiadis L, Mazarakou G, Merkouris M, Hyde K and Hamm H. (2006) Selective interactions between $\mathrm{G}$ protein subunits and RGS4 with the C-terminal domains of the mu- and deltaopioid receptors regulate opioid receptor signaling. Cell. Signal. 18: 771-82 [PMID:16120478]

141. Gerber KJ, Dammer EB, Duong DM, Deng Q, Dudek SM, Seyfried NT and Hepler JR. (2019) Specific Proteomes of Hippocampal Regions CA2 and CA1 Reveal Proteins Linked to the Unique Physiology of Area CA2. J Proteome Res 18: 2571-2584 [PMID:31059263]

142. Gerber KJ, Squires KE and Hepler JR. (2018) 14-3-3y binds regulator of G protein signaling 14 (RGS14) at distinct sites to inhibit the RGS14:Gai-AlF ${ }_{4}^{-}$signaling complex and RGS14 nuclear localization. J Biol Chem 293: 14616-14631 [PMID:30093406]

143. Gerstner JR, Vander Heyden WM, Lavaute TM and Landry CF. (2006) Profiles of novel diurnally regulated genes in mouse hypothalamus: expression analysis of the cysteine and histidine-rich domain-containing, zinc-binding protein 1 , the fatty acid-binding protein 7 and the GTPase, ras-like family member $11 \mathrm{~b}$. Neuroscience 139: 1435-48 [PMID:16517089]

144. Geurts M, Maloteaux JM and Hermans E. (2003) Altered expression of regulators of G-protein signaling (RGS) mRNAs in the striatum of rats undergoing dopamine depletion. Biochem Pharmacol 66: 1163-70 [PMID:14505795]

145. Gibbons DL, Abeler-Dörner L, Raine T, Hwang IY, Jandke A, Wencker M, Deban L, Rudd CE, Irving PM and Kehrl JH et al.. (2011) Cutting Edge: Regulator of $G$ protein signaling-1 selectively regulates gut $T$ cell trafficking and colitic potential. J. Immunol. 187: 2067-71 [PMID:21795595]

146. Glick JL, Meigs TE, Miron A and Casey PJ. (1998) RGSZ1, a Gz-selective regulator of G protein signaling whose action is sensitive to the phosphorylation state of Gzalpha. J. Biol. Chem. 273: 26008-13 [PMID:9748279]

147. Gold SJ, Hoang CV, Potts BW, Porras G, Pioli E, Kim KW, Nadjar A, Qin C, LaHoste GJ and Li œt al.. (2007) RGS9-2 negatively modulates L-3,4-dihydroxyphenylalanine-induced dyskinesia in experimental Parkinson's disease. J. Neurosci. 27: 14338-48 [PMID:18160641]

148. Gold SJ, Ni YG, Dohlman HG and Nestler EJ. (1997) Regulators of G-protein signaling (RGS) proteins: region-specific expression of nine subtypes in rat brain. J. Neurosci. 17: 8024-37 [PMID:9315921]

149. González-Castro TB, Martínez-Magaña JJ, Tovilla-Zárate CA, Juárez-Rojop IE, Sarmiento E, GenisMendoza AD and Nicolini H. (2019) Gene-level genome-wide association analysis of suicide attempt, a preliminary study in a psychiatric Mexican population. Mol Genet Genomic Med 7: e983 [PMID:31578828]

150. Grafstein-Dunn E, Young KH, Cockett MI and Khawaja XZ. (2001) Regional distribution of regulators of Gprotein signaling (RGS) 1, 2, 13, 14, 16, and GAIP messenger ribonucleic acids by in situ hybridization in rat brain. Brain Res. Mol. Brain Res. 88: 113-23 [PMID:11295237]

151. Grillet N, Pattyn A, Contet C, Kieffer BL, Goridis C and Brunet JF. (2005) Generation and characterization of Rgs4 mutant mice. Mol. Cell. Biol. 25: 4221-8 [PMID:15870291]

152. Gross JD, Kaski SW, Schmidt KT, Cogan ES, Boyt KM, Wix K, Schroer AB, McElligott ZA, Siderovski DP and Setola V. (2019) Role of RGS12 in the differential regulation of kappa opioid receptor-dependent signaling and behavior. Neuropsychopharmacology 44: 1728-1741 [PMID:31141817]

153. Gross JD, Kaski SW, Schroer AB, Wix KA, Siderovski DP and Setola V. (2018) Regulator of G protein signaling-12 modulates the dopamine transporter in ventral striatum and locomotor responses to 
psychostimulants. J Psychopharmacol 32: 191-203 [PMID:29364035]

154. Gross V, Tank J, Obst M, Plehm R, Blumer KJ, Diedrich A, Jordan J and Luft FC. (2005) Autonomic nervous system and blood pressure regulation in RGS2-deficient mice. Am. J. Physiol. Regul. Integr. Comp. Physiol. 288: R1134-42 [PMID:15661972]

155. Grüning W, Arnould T, Jochimsen F, Sellin L, Ananth S, Kim E and Walz G. (1999) Modulation of renal tubular cell function by RGS3. Am. J. Physiol. 276: F535-43 [PMID:10198412]

156. Guipponi M, Santoni FA, Setola V, Gehrig C, Rotharmel M, Cuenca M, Guillin O, Dikeos D, Georgantopoulos G and Papadimitriou G et al.. (2014) Exome sequencing in 53 sporadic cases of schizophrenia identifies 18 putative candidate genes. PLoS ONE 9: e112745 [PMID:25420024]

157. Gunaje JJ, Bahrami AJ, Schwartz SM, Daum G and Mahoney Jr WM. (2011) PDGF-dependent regulation of regulator of $\mathrm{G}$ protein signaling-5 expression and vascular smooth muscle cell functionality. Am. J. Physiol., Cell Physiol. 301: C478-89 [PMID:21593453]

158. Guo CC, Wang M, Cao FD, Huang WH, Xiao D, Ye XG, Ou ML, Zhang N, Zhang BH and Liu Yet al.. (2016) Meta-Analysis on Associations of RGS1 and IL12A Polymorphisms with Celiac Disease Risk. Int $J$ Mol Sci 17: [PMID:27043536]

159. Gurley SB, Griffiths RC, Mendelsohn ME, Karas RH and Coffman TM. (2010) Renal actions of RGS2 control blood pressure. J. Am. Soc. Nephrol.21: 1847-51 [PMID:20847141]

160. Hague C, Bernstein LS, Ramineni S, Chen Z, Minneman KP and Hepler JR. (2005) Selective inhibition of alpha1A-adrenergic receptor signaling by RGS2 association with the receptor third intracellular loop. J. Biol. Chem. 280: 27289-95 [PMID:15917235]

161. Hajdu-Cronin YM, Chen WJ, Patikoglou G, Koelle MR and Sternberg PW. (1999) Antagonism between $\mathrm{G}(\mathrm{o})$ alpha and $\mathrm{G}(\mathrm{q})$ alpha in Caenorhabditis elegans: the RGS protein EAT-16 is necessary for $\mathrm{G}(0)$ alpha signaling and regulates G(q)alpha activity. Genes Dev. 13: 1780-93 [PMID:10421631]

162. Haller C, Fillatreau S, Hoffmann R and Agenès F. (2002) Structure, chromosomal localization and expression of the mouse regulator of G-protein signaling10 gene (mRGS10). Gene 297: 39-49 [PMID:12384284]

163. Hamzah J, Jugold M, Kiessling F, Rigby P, Manzur M, Marti HH, Rabie T, Kaden S, Gröne HJ and Hämmerling GJ et al.. (2008) Vascular normalization in Rgs5-deficient tumours promotes immune destruction. Nature 453: 410-4 [PMID:18418378]

164. Han JI, Huang NN, Kim DU and Kehrl JH. (2006) RGS1 and RGS13 mRNA silencing in a human B lymphoma line enhances responsiveness to chemoattractants and impairs desensitization. J. Leukoc. Biol. 79: 1357-68 [PMID:16565322]

165. Han SB, Moratz C, Huang NN, Kelsall B, Cho H, Shi CS, Schwartz O and Kehrl JH. (2005) Rgs1 and Gnai2 regulate the entrance of $B$ lymphocytes into lymph nodes and B cell motility within lymph node follicles. Immunity 22: 343-54 [PMID:15780991]

166. Hao J, Michalek C, Zhang W, Zhu M, Xu X and Mende U. (2006) Regulation of cardiomyocyte signaling by RGS proteins: differential selectivity towards $G$ proteins and susceptibility to regulation. J. Mol. Cell. Cardiol. 41: 51-61 [PMID:16756988]

167. Hartong DT, Pott JW and Kooijman AC. (2007) Six patients with bradyopsia (slow vision): clinical features and course of the disease. Ophthalmology 114: 2323-31 [PMID:17826834]

168. Hayasaka N, Aoki K, Kinoshita S, Yamaguchi S, Wakefield JK, Tsuji-Kawahara S, Horikawa K, Ikegami H, Wakana S and Murakami T et al.. (2011) Attenuated food anticipatory activity and abnormal circadian locomotor rhythms in Rgs16 knockdown mice. PLoS ONE 6: e17655 [PMID:21408016]

169. He W, Cowan CW and Wensel TG. (1998) RGS9, a GTPase accelerator for phototransduction.Neuron 20: 95-102 [PMID:9459445]

170. Hendriks-Balk MC, Hajji N, van Loenen PB, Michel MC, Peters SL and Alewijnse AE. (2009) Sphingosine1-phosphate regulates RGS2 and RGS16 mRNA expression in vascular smooth muscle cells. Eur. J. Pharmacol. 606: 25-31 [PMID:19374869]

171. Hendriks-Balk MC, van Loenen PB, Hajji N, Michel MC, Peters SL and Alewijnse AE. (2008) S1P receptor signalling and RGS proteins; expression and function in vascular smooth muscle cells and transfected CHO cells. Eur. J. Pharmacol. 600: 1-9 [PMID:18854184]

172. Hensch NR, Karim ZA, Druey KM, Tansey MG and Khasawneh FT. (2016) RGS10 Negatively Regulates Platelet Activation and Thrombogenesis. PLoS One 11: e0165984 [PMID:27829061]

173. Hepler JR. (1999) Emerging roles for RGS proteins in cell signalling.Trends Pharmacol. Sci. 20: $376-82$ [PMID:10462761]

174. Hepler JR. (2005) R7BP: a surprising new link between G proteins, RGS proteins, and nuclear signaling in the brain. Sci. STKE 2005: pe38 [PMID:16046666]

175. Hepler JR, Cladman W, Ramineni S, Hollinger S and Chidiac P. (2005) Novel activity of RGS14 on Goalpha and Gialpha nucleotide binding and hydrolysis distinct from its RGS domain and GDI activity. Biochemistry 44: 5495-502 [PMID:15807543]

176. Hercule HC, Tank J, Plehm R, Wellner M, da Costa Goncalves AC, Gollasch M, Diedrich A, Jordan J, Luft FC and Gross V. (2007) Regulator of G protein signalling 2 ameliorates angiotensin II-induced hypertension in mice. Exp. Physiol. 92: 1014-22 [PMID:17644703]

177. Heximer SP, Cristillo AD and Forsdyke DR. (1997) Comparison of mRNA expression of two regulators of G-protein signaling, RGS1/BL34/1R20 and RGS2/G0S8, in cultured human blood mononuclear cells. DNA Cell Biol. 16: 589-98 [PMID:9174164]

178. Heximer SP, Knutsen RH, Sun X, Kaltenbronn KM, Rhee MH, Peng N, Oliveira-dos-Santos A, Penninger JM, Muslin AJ and Steinberg TH et al.. (2003) Hypertension and prolonged vasoconstrictor signaling in 
RGS2-deficient mice. J. Clin. Invest. 111: 445-52 [PMID:12588882]

179. Heximer SP, Srinivasa SP, Bernstein LS, Bernard JL, Linder ME, Hepler JR and Blumer KJ. (1999) G protein selectivity is a determinant of RGS2 function. J. Biol. Chem. 274: 34253-9 [PMID:10567399]

180. Heximer SP, Watson N, Linder ME, Blumer KJ and Hepler JR. (1997) RGS2/G0S8 is a selective inhibitor of Gqalpha function. Proc. Natl. Acad. Sci. U.S.A. 94: 14389-93 [PMID:9405622]

181. Hishimoto A, Shirakawa O, Nishiguchi N, Aoyama S, Ono H, Hashimoto T and Maeda K. (2004) Novel missense polymorphism in the regulator of G-protein signaling 10 gene: analysis of association with schizophrenia. Psychiatry Clin Neurosci 58: 579-81 [PMID:15482592]

182. Hohoff C, Weber H, Richter J, Domschke K, Zwanzger PM, Ohrmann P, Bauer J, Suslow T, Kugel H and Baumann C et al.. (2015) RGS2 ggenetic variation: association analysis with panic disorder and dimensional as well as intermediate phenotypes of anxiety. Am. J. Med. Genet. B Neuropsychiatr. Genet. 168B: 211-22 [PMID:25740197]

183. Hollinger S and Hepler JR. (2002) Cellular regulation of RGS proteins: modulators and integrators of $G$ protein signaling. Pharmacol. Rev. 54: 527-59 [PMID:12223533]

184. Hollinger S, Ramineni S and Hepler JR. (2003) Phosphorylation of RGS14 by protein kinase A potentiates its activity toward G alpha i. Biochemistry 42: 811-9 [PMID:12534294]

185. Hollinger S, Taylor JB, Goldman EH and Hepler JR. (2001) RGS14 is a bifunctional regulator of Galphai/o activity that exists in multiple populations in brain. J. Neurochem. 79: 941-9 [PMID:11739605]

186. Holobotovskyy V, Chong YS, Burchell J, He B, Phillips M, Leader L, Murphy TV, Sandow SL, McKitrick DJ and Charles AK et al.. (2015) Regulator of G protein signaling 5 is a determinant of gestational hypertension and preeclampsia. Sci Transl Med7: 290ra88 [PMID:26041705]

187. Holobotovskyy V, Manzur M, Tare M, Burchell J, Bolitho E, Viola H, Hool LC, Arnolda LF, McKitrick DJ and Ganss R. (2013) Regulator of G-protein signaling 5 controls blood pressure homeostasis and vessel wall remodeling. Circ. Res. 112: 781-91 [PMID:23303165]

188. Honda K, Satomura K, Hashida M and Sezaki H. (1985) [Topical application of mitomycin C conjugated with dextran (MMC-D): a high molecular weight derivative of mitomycin C]. Gan To Kagaku Ryoho 12: 5305 [PMID:2408576]

189. Hong JX, Wilson GL, Fox CH and Kehrl JH. (1993) Isolation and characterization of a novel B cell activation gene. J. Immunol. 150: 3895-904 [PMID:8473738]

190. Hooks SB, Callihan P, Altman MK, Hurst JH, Ali MW and Murph MM. (2010) Regulators of G-Protein signaling RGS10 and RGS17 regulate chemoresistance in ovarian cancer cells. Mol. Cancer 9: 289 [PMID:21044322]

191. Hooks SB and Murph MM. (2015) Cellular deficiency in the RGS10 protein facilitates chemoresistant ovarian cancer. Future Med Chem 7: 1483-9 [PMID:26293348]

192. Hooks SB, Waldo GL, Corbitt J, Bodor ET, Krumins AM and Harden TK. (2003) RGS6, RGS7, RGS9, and RGS11 stimulate GTPase activity of Gi family G-proteins with differential selectivity and maximal activity. $J$. Biol. Chem. 278: 10087-93 [PMID:12531899]

193. Howlett AC, Gray AJ, Hunter JM and Willardson BM. (2009) Role of molecular chaperones in G protein beta5/regulator of $\mathrm{G}$ protein signaling dimer assembly and $\mathrm{G}$ protein betagamma dimer specificity. J. Biol. Chem. 284: 16386-99 [PMID:19376773]

194. Hsu HC, Yang P, Wang J, Wu Q, Myers R, Chen J, Yi J, Guentert T, Tousson A and Stanus Alet al.. (2008) Interleukin 17-producing T helper cells and interleukin 17 orchestrate autoreactive germinal center development in autoimmune BXD2 mice. Nat. Immunol. 9: 166-75 [PMID:18157131]

195. Hu G and Wensel TG. (2002) R9AP, a membrane anchor for the photoreceptor GTPase accelerating protein, RGS9-1. Proc. Natl. Acad. Sci. U.S.A. 99: 9755-60 [PMID:12119397]

196. Hu M, Chen X, Zhang J, Wang D, Fang X, Wang X, Wang G, Chen G, Jiang X and Xia Het al.. (2013) Over-expression of regulator of $G$ protein signaling 5 promotes tumor metastasis by inducing epithelialmesenchymal transition in hepatocellular carcinoma cells. J Surg Oncol 108: 192-6 [PMID:23868206]

197. Hu Y, Shmygelska A, Tran D, Eriksson N, Tung JY and Hinds DA. (2016) GWAS of 89,283 individuals identifies genetic variants associated with self-reporting of being a morning person. Nat Commun 7: 10448 [PMID:26835600]

198. Huang J, Nalli AD, Mahavadi S, Kumar DP and Murthy KS. (2014) Inhibition of Gai activity by GßY is mediated by PI 3-kinase- $\gamma$ - and cSrc-dependent tyrosine phosphorylation of Gai and recruitment of RGS12. Am. J. Physiol. Gastrointest. Liver Physiol. 306: G802-10 [PMID:24578342]

199. Huang J, Pashkov V, Kurrasch DM, Yu K, Gold SJ and Wilkie TM. (2006) Feeding and fasting controls liver expression of a regulator of $G$ protein signaling (Rgs16) in periportal hepatocytes. Comp Hepatol 5: 8 [PMID:17123436]

200. Huang J, Stewart A, Maity B, Hagen J, Fagan RL, Yang J, Quelle DE, Brenner C and Fisher RA. (2014) RGS6 suppresses Ras-induced cellular transformation by facilitating Tip60-mediated Dnmt1 degradation and promoting apoptosis. Oncogene 33: 3604-11 [PMID:23995786]

201. Huang J, Yang J, Maity B, Mayuzumi D and Fisher RA. (2011) Regulator of G protein signaling 6 mediates doxorubicin-induced ATM and p53 activation by a reactive oxygen species-dependent mechanism. Cancer Res. 71: 6310-9 [PMID:21859827]

202. Hunt KA, Zhernakova A, Turner G, Heap GA, Franke L, Bruinenberg M, Romanos J, Dinesen LC, Ryan AW and Panesar D et al.. (2008) Newly identified genetic risk variants for celiac disease related to the immune response. Nat. Genet. 40: 395-402 [PMID:18311140]

203. Hunt RA, Edris W, Chanda PK, Nieuwenhuijsen B and Young KH. (2003) Snapin interacts with the N- 
terminus of regulator of $\mathrm{G}$ protein signaling 7. Biochem. Biophys. Res. Commun. 303: 594-9

[PMID:12659861]

204. Hunt TW, Fields TA, Casey PJ and Peralta EG. (1996) RGS10 is a selective activator of G alpha i GTPase activity. Nature 383: 175-7 [PMID:8774883]

205. Hurst JH and Hooks SB. (2009) Regulator of G-protein signaling (RGS) proteins in cancer biology. Biochem. Pharmacol. 78: 1289-97 [PMID:19559677]

206. Hwang IY, Hwang KS, Park C, Harrison KA and Kehrl JH. (2013) Rgs13 constrains early B cell responses and limits germinal center sizes. PLoS ONE 8: e60139 [PMID:23533672]

207. Häggmark A, Mikus M, Mohsenchian A, Hong MG, Forsström B, Gajewska B, Barańczyk-Kuźma A, Uhlén M, Schwenk JM and Kuźma-Kozakiewicz M et al.. (2014) Plasma profiling reveals three proteins associated to amyotrophic lateral sclerosis. Ann Clin Transl Neurol1: 544-53 [PMID:25356426]

208. Ikeda M, Hirokawa M, Satani N, Kinoshita T, Watanabe Y, Inoue H, Tone S, Ishikawa T and Minatogawa Y. (2001) Molecular cloning and characterization of a steroid receptor-binding regulator of G-protein signaling protein cDNA. Gene 273: 207-14 [PMID:11595167]

209. Im EJ, Yayeh T, Park SJ, Kim SH, Goo YK, Hong SB, Son YM, Kim SD and Rhee MH. (2014) Antiatherosclerotic effect of korean red ginseng extract involves regulator of g-protein signaling 5 . Evid Based Complement Alternat Med 2014: 985174 [PMID:25610490]

210. Ingi T, Krumins AM, Chidiac P, Brothers GM, Chung S, Snow BE, Barnes CA, Lanahan AA, Siderovski DP and Ross EM et al.. (1998) Dynamic regulation of RGS2 suggests a novel mechanism in G-protein signaling and neuronal plasticity. J. Neurosci. 18: 7178-88 [PMID:9736641]

211. International Multiple Sclerosis Genetics Consortium, Wellcome Trust Case Control Consortium 2, Sawcer S, Hellenthal G, Pirinen M, Spencer CC, Patsopoulos NA, Moutsianas L, Dilthey A and Su Z et al.. (2011) Genetic risk and a primary role for cell-mediated immune mechanisms in multiple sclerosis. Nature 476: 214-9 [PMID:21833088]

212. International Multiple Sclerosis Genetics Conssortium (IMSGC). (2010) IL12A, MPHOSPH9/CDK2AP1 and RGS1 are novel multiple sclerosis susceptibility loci. Genes Immun. 11: 397-405 [PMID:20555355]

213. Islam TC, Asplund AC, Lindvall JM, Nygren L, Liden J, Kimby E, Christensson B, Smith Cl and Sander B. (2003) High level of cannabinoid receptor 1, absence of regulator of $G$ protein signalling 13 and differential expression of Cyclin D1 in mantle cell lymphoma. Leukemia 17: 1880-90 [PMID:12970790]

214. Israeli R, Asli A, Avital-Shacham M and Kosloff M. (2019) RGS6 and RGS7 Discriminate between the Highly Similar $\mathrm{Ga}_{\mathrm{i}}$ and $\mathrm{G \alpha}$ o Proteins Using a Two-Tiered Specificity Strategy. J. Mol. Biol. 431: $3302-3311$ [PMID:31153905]

215. Itoh M, Nagatomo K, Kubo $Y$ and Saitoh O. (2006) Alternative splicing of RGS8 gene changes the binding property to the M1 muscarinic receptor to confer receptor type-specific Gq regulation. J. Neurochem. 99: 1505-16 [PMID:17064349]

216. Itoh M, Odagiri M, Abe H and Saitoh O. (2001) RGS8 protein is distributed in dendrites and cell body of cerebellar Purkinje cell. Biochem. Biophys. Res. Commun. 287: 223-8 [PMID:11549278]

217. Iwai K, Koike M, Ohshima S, Miyatake K, Uchiyama Y, Saeki Y and Ishii M. (2007) RGS18 acts as a negative regulator of osteoclastogenesis by modulating the acid-sensing OGR1/NFAT signaling pathway. J. Bone Miner. Res. 22: 1612-20 [PMID:17576169]

218. Iwaki S, Lu Y, Xie Z and Druey KM. (2011) p53 negatively regulates RGS13 protein expression in immune cells. J. Biol. Chem. 286: 22219-26 [PMID:21531726]

219. Izzo V, Pinelli M, Tinto N, Esposito MV, Cola A, Sperandeo MP, Tucci F, Cocozza S, Greco L and Sacchetti L. (2011) Improving the estimation of celiac disease sibling risk by non-HLA genes. PLoS ONE 6: e26920 [PMID:22087237]

220. Jayaraman M, Zhou H, Jia L, Cain MD and Blumer KJ. (2009) R9AP and R7BP: traffic cops for the RGS7 family in phototransduction and neuronal GPCR signaling. Trends Pharmacol. Sci. 30: 17-24 [PMID:19042037]

221. Jaén C and Doupnik CA. (2006) RGS3 and RGS4 differentially associate with G protein-coupled receptorKir3 channel signaling complexes revealing two modes of RGS modulation. Precoupling and collision coupling. J. Biol. Chem. 281: 34549-60 [PMID:16973624]

222. Jean-Baptiste G, Li X, Yang Z, Heubach J, Gaudio S, Khoury C, Ravens U and Greenwood MT. (2005) Beta adrenergic receptor-mediated atrial specific up-regulation of RGS5. Life Sci. 76: 1533-45 [PMID:15680317]

223. Jeffrey BG, Morgans CW, Puthussery T, Wensel TG, Burke NS, Brown RL and Duvoisin RM. (2010) R9AP stabilizes RGS11-G beta5 and accelerates the early light response of ON-bipolar cells. Vis. Neurosci. 27: 9-17 [PMID:20100392]

224. Jiang H, Xie Y, Abel PW, Wolff DW, Toews ML, Panettieri Jr RA, Casale TB and Tu Y. (2015) Regulator of G-Protein Signaling 2 Repression Exacerbates Airway Hyper-Responsiveness and Remodeling in Asthma. Am. J. Respir. Cell Mol. Biol. 53: 42-9 [PMID:25368964]

225. Jin Y, An X, Ye Z, Cully B, Wu J and Li J. (2009) RGS5, a hypoxia-inducible apoptotic stimulator in endothelial cells. J. Biol. Chem. 284: 23436-43 [PMID:19564336]

226. Jin Y, Zhong H, Omnaas JR, Neubig RR and Mosberg HI. (2004) Structure-based design, synthesis, and pharmacologic evaluation of peptide RGS4 inhibitors. J. Pept. Res. 63: 141-6 [PMID:15009535]

227. Johnson BA, Wang J, Taylor EM, Caillier SJ, Herbert J, Khan OA, Cross AH, De Jager PL, Gourraud PA and Cree BC et al.. (2010) Multiple sclerosis susceptibility alleles in African Americans.Genes Immun. 11: 343-50 [PMID:19865102] 
228. Johnson EN and Druey KM. (2002) Functional characterization of the G protein regulator RGS13J. Biol. Chem. 277: 16768-74 [PMID:11875076]

229. Johnson EN, Seasholtz TM, Waheed AA, Kreutz B, Suzuki N, Kozasa T, Jones TL, Brown JH and Druey KM. (2003) RGS16 inhibits signalling through the G alpha 13-Rho axis. Nat. Cell Biol. 5: 1095-103 [PMID:14634662]

230. Kannarkat GT, Lee JK, Ramsey CP, Chung J, Chang J, Porter I, Oliver D, Shepherd K and Tansey MG. (2015) Age-related changes in regulator of G-protein signaling (RGS)-10 expression in peripheral and central immune cells may influence the risk for age-related degeneration. Neurobiol Aging 36: 1982-93 [PMID:25784210]

231. Kardestuncer T, Wu H, Lim AL and Neer EJ. (1998) Cardiac myocytes express mRNA for ten RGS proteins: changes in RGS mRNA expression in ventricular myocytes and cultured atria. FEBS Lett. 438: 285-8 [PMID:9827562]

232. Karpinsky-Semper D, Volmar CH, Brothers SP and Slepak VZ.. (2014) Differential effects of the Gß5RGS7 complex on muscarinic M3 receptor-induced Ca2+ influx and release. Mol Pharmacol. 85: 758-68 [PMID:24586057]

233. Kauppila A, Mäkilä UM, Mäkäräinen L, Puolakka J and Seppälä A. (1986) Tiaprofenic acid in the treatment of primary dysmenorrhoea. Eur. J. Obstet. Gynecol. Reprod. Biol. 22: 359-63 [PMID:3533672]

234. Kehrl JH, Srikumar D, Harrison K, Wilson GL and Shi CS. (2002) Additional 5' exons in the RGS3 locus generate multiple mRNA transcripts, one of which accounts for the origin of human PDZ-RGS3. Genomics 79: 860-8 [PMID:12036301]

235. Ketsawatsomkron P, Lorca RA, Keen HL, Weatherford ET, Liu X, Pelham CJ, Grobe JL, Faraci FM, England SK and Sigmund CD. (2012) PPARy regulates resistance vessel tone through a mechanism involving RGS5-mediated control of protein kinase C and BKCa channel activity. Circ. Res. 111: 1446-58 [PMID:22962432]

236. Kim HJ, Min JY and Min KB. (2017) Interaction between the RGS6 gene and psychosocial stress on obesity-related traits. Endocr. J. 64: 357-362 [PMID:28090039]

237. Kim JH, Lee JY, Lee KT, Lee JK, Lee KH, Jang KT, Heo JS, Choi SH and Rhee JC. (2010) RGS16 and FosB underexpressed in pancreatic cancer with lymph node metastasis promote tumor progression. Tumour Biol. 31: 541-8 [PMID:20571966]

238. Kim W, Bennett EJ, Huttlin EL, Guo A, Li J, Possemato A, Sowa ME, Rad R, Rush J and Comb Mit al.. (2011) Systematic and quantitative assessment of the ubiquitin-modified proteome. Mol. Cell 44: 325-40 [PMID:21906983]

239. Kimple AJ, Garland AL, Cohen SP, Setola V, Willard FS, Zielinski T, Lowery RG, Tarran R and Siderovski DP. (2014) RGS21, a regulator of taste and mucociliary clearance? Laryngoscope 124: E56-63 [PMID:23908053]

240. Kimple AJ, Willard FS, Giguère PM, Johnston CA, Mocanu V and Siderovski DP. (2007) The RGS protein inhibitor CCG-4986 is a covalent modifier of the RGS4 Galpha-interaction face. Biochim. Biophys. Acta 1774: 1213-20 [PMID:17660054]

241. Kimple RJ, De Vries L, Tronchère H, Behe Cl, Morris RA, Gist Farquhar M and Siderovski DP. (2001) RGS12 and RGS14 GoLoco motifs are G alpha(i) interaction sites with guanine nucleotide dissociation inhibitor Activity. J. Biol. Chem. 276: 29275-81 [PMID:11387333]

242. Kirsch T, Wellner M, Luft FC, Haller H and Lippoldt A. (2001) Altered gene expression in cerebral capillaries of stroke-prone spontaneously hypertensive rats. Brain Res. 910: 106-15 [PMID:11489260]

243. Kittanakom S, Barrios-Rodiles M, Petschnigg J, Arnoldo A, Wong V, Kotlyar M, Heisler LE, Jurisica I, Wrana JL and Nislow $C$ et al.. (2014) CHIP-MYTH: a novel interactive proteomics method for the assessment of agonist-dependent interactions of the human $\beta_{2}$-adrenergic receptor. Biochem. Biophys. Res. Commun. 445: 746-56 [PMID:24561123]

244. Ko WK, Martin-Negrier ML, Bezard E, Crossman AR and Ravenscroft P. (2014) RGS4 is involved in the generation of abnormal involuntary movements in the unilateral 6-OHDA-lesioned rat model of Parkinson's disease. Neurobiol. Dis. 70: 138-48 [PMID:24969021]

245. Koelle MR and Horvitz HR. (1996) EGL-10 regulates G protein signaling in the C. elegans nervous system and shares a conserved domain with many mammalian proteins. Cell 84: 115-25 [PMID:8548815]

246. Koh J, Dar M, Untch BR, Dixit D, Shi Y, Yang Z, Adam MA, Dressman H, Wang X and Gesty-Palmer Det al.. (2011) Regulator of $G$ protein signaling 5 is highly expressed in parathyroid tumors and inhibits signaling by the calcium-sensing receptor. Mol. Endocrinol. 25: 867-76 [PMID:21393447]

247. Kohara K, Tabara Y, Nakura J, Imai Y, Ohkubo T, Hata A, Soma M, Nakayama T, Umemura S and Hirawa $\mathrm{N}$ et al.. (2008) Identification of hypertension-susceptibility genes and pathways by a systemic multiple candidate gene approach: the millennium genome project for hypertension. Hypertens. Res. 31: 203-12 [PMID:18360038]

248. Kondo M, Das G, Imai R, Santana E, Nakashita T, Imawaka M, Ueda K, Ohtsuka H, Sakai K and Aihara T et al.. (2015) A Naturally Occurring Canine Model of Autosomal Recessive Congenital Stationary Night Blindness. PLoS ONE 10: e0137072 [PMID:26368928]

249. Kovoor A, Chen CK, He W, Wensel TG, Simon MI and Lester HA. (2000) Co-expression of Gbeta5 enhances the function of two Ggamma subunit-like domain-containing regulators of $\mathrm{G}$ protein signaling proteins. J. Biol. Chem. 275: 3397-402 [PMID:10652332]

250. Kovoor A, Seyffarth P, Ebert J, Barghshoon S, Chen CK, Schwarz S, Axelrod JD, Cheyette BN, Simon MI and Lester HA et al.. (2005) D2 dopamine receptors colocalize regulator of G-protein signaling 9-2 (RGS92) via the RGS9 DEP domain, and RGS9 knock-out mice develop dyskinesias associated with dopamine 
pathways. J. Neurosci. 25: 2157-65 [PMID:15728856]

251. Krispel CM, Chen D, Melling N, Chen YJ, Martemyanov KA, Quillinan N, Arshavsky VY, Wensel TG, Chen CK and Burns ME. (2006) RGS expression rate-limits recovery of rod photoresponses. Neuron 51: 409-16 [PMID:16908407]

252. Krumins AM, Barker SA, Huang C, Sunahara RK, Yu K, Wilkie TM, Gold SJ and Mumby SM. (2004) Differentially regulated expression of endogenous RGS4 and RGS7. J. Biol. Chem. 279: 2593-9 [PMID:14604980]

253. Kulkarni K, Xie X, Marron Fernandez de Velasco E, Anderson A, Martemyanov KA, Wickman K and Tolkacheva EG. (2018) The influences of the M2R-GIRK4-RGS6 dependent parasympathetic pathway on electrophysiological properties of the mouse heart. PLOS ONE 13: e0193798 [PMID:29668674]

254. Kurogi M, Nagatomo K, Kubo Y and Saitoh O. (2009) Effects of spinophilin on the function of RGS8 regulating signals from M2 and M3-mAChRs. Neuroreport 20: 1134-9 [PMID:19609226]

255. Kurrasch DM, Huang J, Wilkie TM and Repa JJ. (2004) Quantitative real-time polymerase chain reaction measurement of regulators of G-protein signaling mRNA levels in mouse tissues. Meth. Enzymol. 389: 315 [PMID:15313556]

256. Kuwata H, Nakao K, Harada T, Matsuda I and Aiba A. (2008) Generation of RGS8 null mutant mice by Cre/loxP system. Kobe J Med Sci53: 275-81 [PMID:18762722]

257. Kveberg L, Ryan JC, Rolstad B and Inngjerdingen M. (2005) Expression of regulator of G protein signalling proteins in natural killer cells, and their modulation by Ly49A and Ly49D. Immunology 115: 35865 [PMID:15946253]

258. Labuda M, Laberge S, Brière J, Bérubé D and Krajinovic M. (2013) RGS5 gene and therapeutic response to short acting bronchodilators in paediatric asthma patients. Pediatr. Pulmonol. 48: 970-5 [PMID:23193110]

259. Larminie C, Murdock P, Walhin JP, Duckworth M, Blumer KJ, Scheideler MA and Garnier M. (2004) Selective expression of regulators of G-protein signaling (RGS) in the human central nervous system. Brain Res. Mol. Brain Res. 122: 24-34 [PMID:14992813]

260. Laroche G, Giguère PM, Roth BL, Trejo J and Siderovski DP. (2010) RNA interference screen for RGS protein specificity at muscarinic and protease-activated receptors reveals bidirectional modulation of signaling. Am. J. Physiol., Cell Physiol. 299: C654-64 [PMID:20573995]

261. Lee EK, Ye Y, Kamat AM and Wu X. (2013) Genetic variations in regulator of G-protein signaling (RGS) confer risk of bladder cancer. Cancer 119: 1643-51 [PMID:23529717]

262. Lee J and Ghil S. (2016) Regulator of G protein signaling 8 inhibits protease-activated receptor $1 / \mathrm{Gi} / \mathrm{o}$ signaling by forming a distinct $\mathrm{G}$ protein-dependent complex in live cells. Cell. Signal. 28: 391-400 [PMID:26829215]

263. Lee JK, Chung J, Druey KM and Tansey MG. (2012) RGS10 exerts a neuroprotective role through the PKA/c-AMP response-element (CREB) pathway in dopaminergic neuron-like cells. J Neurochem 122: 33343 [PMID:22564151]

264. Lee JK, Chung J, Kannarkat GT and Tansey MG. (2013) Critical role of regulator G-protein signaling 10 (RGS10) in modulating macrophage M1/M2 activation. PLoS ONE 8: e81785 [PMID:24278459]

265. Lee JK, Chung J, McAlpine FE and Tansey MG. (2011) Regulator of G-protein signaling-10 negatively regulates NF-KB in microglia and neuroprotects dopaminergic neurons in hemiparkinsonian rats. J. Neurosci. 31: 11879-88 [PMID:21849548]

266. Lee JK, Kannarkat GT, Chung J, Joon Lee H, Graham KL and Tansey MG. (2016) RGS10 deficiency ameliorates the severity of disease in experimental autoimmune encephalomyelitis. $J$ Neuroinflammation 13: 24 [PMID:26831924]

267. Lee JK, McCoy MK, Harms AS, Ruhn KA, Gold SJ and Tansey MG. (2008) Regulator of G-protein signaling 10 promotes dopaminergic neuron survival via regulation of the microglial inflammatory response. J. Neurosci. 28: 8517-28 [PMID:18716210]

268. Lee JK and Tansey MG. (2015) Physiology of RGS10 in Neurons and Immune Cells Prog Mol Biol Transl Sci 133: 153-67 [PMID:26123306]

269. Lee SE, Simons SB, Heldt SA, Zhao M, Schroeder JP, Vellano CP, Cowan DP, Ramineni S, Yates CK and Feng Y et al.. (2010) RGS14 is a natural suppressor of both synaptic plasticity in CA2 neurons and hippocampal-based learning and memory. Proc. Natl. Acad. Sci. U.S.A. 107: 16994-8 [PMID:20837545]

270. Leontiadis LJ, Papakonstantinou MP and Georgoussi Z. (2009) Regulator of G protein signaling 4 confers selectivity to specific $\mathrm{G}$ proteins to modulate mu- and delta-opioid receptor signaling. Cell. Signal. 21: 1218-28 [PMID:19324084]

271. Lerner TN and Kreitzer AC. (2012) RGS4 is required for dopaminergic control of striatal LTD and susceptibility to parkinsonian motor deficits. Neuron 73: 347-59 [PMID:22284188]

272. Leygraf A, Hohoff C, Freitag C, Willis-Owen SA, Krakowitzky P, Fritze J, Franke P, Bandelow B, Fimmers $\mathrm{R}$ and Flint $\mathrm{J}$ et al.. (2006) Rgs 2 gene polymorphisms as modulators of anxiety in humans?J Neural Transm 113: 1921-5 [PMID:16736243]

273. Li H, He C, Feng J, Zhang Y, Tang Q, Bian Z, Bai X, Zhou H, Jiang H and Heximer Spet al.. (2010) Regulator of $\mathrm{G}$ protein signaling 5 protects against cardiac hypertrophy and fibrosis during biomechanical stress of pressure overload. Proc. Natl. Acad. Sci. U.S.A. 107: 13818-23 [PMID:20643937]

274. Li J, Adams LD, Wang X, Pabon L, Schwartz SM, Sane DC and Geary RL. (2004) Regulator of G protein signaling 5 marks peripheral arterial smooth muscle cells and is downregulated in atherosclerotic plaque. J. Vasc. Surg. 40: 519-28 [PMID:15337883] 
275. Li S, Jin X, Wu H, Wang Y, Li X, Guo Y and Liang S. (2017) HA117 endows HL60 cells with a stem-like signature by inhibiting the degradation of DNMT1 via its ability to down-regulate expression of the GGL domain of RGS6. PLOS ONE 12: e0180142 [PMID:28665981]

276. Li X, Chen L, Ji C, Liu B, Gu J, Xu J, Zou X, Gu S and Mao Y. (2005) Isolation and expression pattern of RGS21 gene, a novel RGS member. Acta Biochim. Pol. 52: 943-6 [PMID:16302027]

277. Li Y, Tang XH, Li XH, Dai HJ, Miao RJ, Cai JJ, Huang ZJ, Chen AF, Xing XW and Lu Yet al.. (2016) Regulator of $G$ protein signalling 14 attenuates cardiac remodelling through the MEK-ERK1/2 signalling pathway. Basic Res Cardiol 111: 47 [PMID:27298141]

278. Li Z, Liu T, Gilmore A, Gómez NM, Fu C, Lim J, Yang S, Mitchell CH, Li YP and Oursler Mæt al.. (2019) Regulator of G Protein Signaling Protein 12 (Rgs12) Controls Mouse Osteoblast Differentiation via Calcium Channel/Oscillation and Gai-ERK Signaling. J Bone Miner Res 34: 752-764 [PMID:30489658]

279. Liang G, Bansal G, Xie Z and Druey KM. (2009) RGS16 inhibits breast cancer cell growth by mitigating phosphatidylinositol 3-kinase signaling. J. Biol. Chem. 284: 21719-27 [PMID:19509421]

280. Liang Y, Li C, Guzman VM, Chang WW, Evinger 3rd AJ, Sao D and Woodward DF. (2005) Identification of a novel alternative splicing variant of RGS5 mRNA in human ocular tissues. FEBS J. 272: 791-9 [PMID:15670159]

281. Lifschytz T, Broner EC, Zozulinsky P, Slonimsky A, Eitan R, Greenbaum L and Lerer B. (2012) Relationship between Rgs2 gene expression level and anxiety and depression-like behaviour in a mutant mouse model: serotonergic involvement. Int. J. Neuropsychopharmacol. 15: 1307-18 [PMID:22040681]

282. Linder ME and Deschenes RJ. (2007) Palmitoylation: policing protein stability and traffic.Nat. Rev. Mol. Cell Biol. 8: 74-84 [PMID:17183362]

283. Lippert E, Yowe DL, Gonzalo JA, Justice JP, Webster JM, Fedyk ER, Hodge M, Miller C, Gutierrez-Ramos $\mathrm{JC}$ and Borrego $\mathrm{F}$ et al.. (2003) Role of regulator of $\mathrm{G}$ protein signaling 16 in inflammation-induced $\mathrm{T}$ lymphocyte migration and activation. J. Immunol. 171: 1542-55 [PMID:12874248]

284. Liu P, Zhang C, Chen J, Zhang R, Ren J, Huang Y, Zhu F, Li Z and Wu G. (2011) Combinational therapy of interferon- $\alpha$ and chemotherapy normalizes tumor vasculature by regulating pericytes including the novel marker RGS5 in melanoma. J. Immunother. 34: 320-6 [PMID:21389866]

285. Liu W, Yuen EY, Allen PB, Feng J, Greengard P and Yan Z. (2006) Adrenergic modulation of NMDA receptors in prefrontal cortex is differentially regulated by RGS proteins and spinophilin. Proc. Natl. Acad. Sci. U.S.A. 103: 18338-43 [PMID:17101972]

286. Liu Y, Huang H, Zhang Y, Zhu XY, Zhang R, Guan LH, Tang Q, Jiang H and Huang C. (2014) Regulator of $\mathrm{G}$ protein signaling 3 protects against cardiac hypertrophy in mice. J. Cell. Biochem. 115: 977-86 [PMID:24375609]

287. Liu Z, Chatterjee TK and Fisher RA. (2002) RGS6 interacts with SCG10 and promotes neuronal differentiation. Role of the G gamma subunit-like (GGL) domain of RGS6. J. Biol. Chem. 277: 37832-9 [PMID:12140291]

288. Liu Z and Fisher RA. (2004) RGS6 interacts with DMAP1 and DNMT1 and inhibits DMAP1 transcriptional repressor activity. J. Biol. Chem. 279: 14120-8 [PMID:14734556]

289. Louwette S, Labarque V, Wittevrongel C, Thys C, Metz J, Gijsbers R, Debyser Z, Arnout J, Van Geet C and Freson K. (2012) Regulator of G-protein signaling 18 controls megakaryopoiesis and the ciliamediated vertebrate mechanosensory system. FASEB J. 26: 2125-36 [PMID:22308195]

290. Lovschall H, Mitsiadis TA, Poulsen K, Jensen KH and Kjeldsen AL. (2007) Coexpression of Notch3 and Rgs5 in the pericyte-vascular smooth muscle cell axis in response to pulp injury. Int. J. Dev. Biol. 51: 71521 [PMID:17939118]

291. Lu J, Gosslau A, Liu AY and Chen KY. (2008) PCR differential display-based identification of regulator of $G$ protein signaling 10 as the target gene in human colon cancer cells induced by black tea polyphenol theaflavin monogallate. Eur J Pharmaco/601: 66-72 [PMID:18992738]

292. Lu Q, Sun EE and Flanagan JG. (2004) Analysis of PDZ-RGS3 function in ephrin-B reverse signaling. Meth. Enzymol. 390: 120-8 [PMID:15488174]

293. Luck K, Kim DK, Lambourne L, Spirohn K, Begg BE, Bian W, Brignall R, Cafarelli T, Campos-Laborie FJ and Charloteaux B et al.. (2020) A reference map of the human binary protein interactome.Nature $\mathbf{5 8 0}$ : 402-408 [PMID:32296183]

294. Luo Y, Qin SL, Yu MH, Mu YF, Wang ZS and Zhong M. (2015) Prognostic value of regulator of G-protein signaling 6 in colorectal cancer. Biomed. Pharmacother. 76: 147-52 [PMID:26653562]

295. Luo Z, Ahlers-Dannen KE, Spicer MM, Yang J, Alberico S, Stevens HE, Narayanan NS and Fisher RA. (2019) Age-dependent nigral dopaminergic neurodegeneration and a-synuclein accumulation in RGS6deficient mice. JCl Insight 5: e126769 [PMID:31120439]

296. Lyu JH, Park DW, Huang B, Kang SH, Lee SJ, Lee C, Bae YS, Lee JG and Baek SH. (2015) RGS2 suppresses breast cancer cell growth via a MCPIP1-dependent pathway. J. Cell. Biochem. 116: 260-7 [PMID:25187114]

297. Lyubarsky AL, Naarendorp F, Zhang X, Wensel T, Simon MI and Pugh Jr EN. (2001) RGS9-1 is required for normal inactivation of mouse cone phototransduction. Mol. Vis. 7: 71-8 [PMID:11262419]

298. López-Aranda MF, Acevedo MJ, Carballo FJ, Gutiérrez A and Khan ZU. (2006) Localization of the GoLoco motif carrier regulator of G-protein signalling 12 and 14 proteins in monkey and rat brain. Eur. J. Neurosci. 23: 2971-82 [PMID:16819986]

299. López-Aranda MF, López-Téllez JF, Navarro-Lobato I, Masmudi-Martín M, Gutiérrez A and Khan ZU. (2009) Role of layer 6 of V2 visual cortex in object-recognition memory. Science 325: 87-9 [PMID:19574389] 
300. Ma P, Cierniewska A, Signarvic R, Cieslak M, Kong H, Sinnamon AJ, Neubig RR, Newman DK, Stalker TJ and Brass LF. (2012) A newly identified complex of spinophilin and the tyrosine phosphatase, SHP-1, modulates platelet activation by regulating $\mathrm{G}$ protein-dependent signaling. Blood 119: 1935-45 [PMID:22210881]

301. Ma P, Foote DC, Sinnamon AJ and Brass LF. (2015) Dissociation of SHP-1 from spinophilin during platelet activation exposes an inhibitory binding site for protein phosphatase-1 (PP1). PLoS ONE 10: e0119496 [PMID:25785436]

302. Ma P, Gupta S, Sampietro S, DeHelian D, Tutwiler V, Tang A, Stalker TJ and Brass LF. (2018) RGS10 shapes the hemostatic response to injury through its differential effects on intracellular signaling by platelet agonists. Blood Adv 2: 2145-2155 [PMID:30150297]

303. Mahoney Jr WM, Gunaje J, Daum G, Dong XR and Majesky MW. (2013) Regulator of G-protein signaling 5 (RGS5) is a novel repressor of hedgehog signaling. PLoS ONE 8: e61421 [PMID:23637832]

304. Maity B, Stewart A, O'Malley Y, Askeland RW, Sugg SL and Fisher RA. (2013) Regulator of G protein signaling 6 is a novel suppressor of breast tumor initiation and progression. Carcinogenesis 34: 1747-55 [PMID:23598467]

305. Maity B, Stewart A, Yang J, Loo L, Sheff D, Shepherd AJ, Mohapatra DP and Fisher RA. (2012) Regulator of $G$ protein signaling 6 (RGS6) protein ensures coordination of motor movement by modulating GABAB receptor signaling. J. Biol. Chem. 287: 4972-81 [PMID:22179605]

306. Maity B, Yang J, Huang J, Askeland RW, Bera S and Fisher RA. (2011) Regulator of G protein signaling 6 (RGS6) induces apoptosis via a mitochondrial-dependent pathway not involving its GTPase-activating protein activity. J. Biol. Chem. 286: 1409-19 [PMID:21041304]

307. Makino ER, Handy JW, Li T and Arshavsky VY. (1999) The GTPase activating factor for transducin in rod photoreceptors is the complex between RGS9 and type $5 \mathrm{G}$ protein beta subunit. Proc. Natl. Acad. Sci. U.S.A. 96: 1947-52 [PMID:10051575]

308. Mao H, Zhao Q, Daigle M, Ghahremani MH, Chidiac P and Albert PR. (2004) RGS17/RGSZ2, a novel regulator of Gi/o, Gz, and Gq signaling. J. Biol. Chem. 279: 26314-22 [PMID:15096504]

309. Mao Y, Lei L, Su J, Yu Y, Liu Z and Huo Y. (2014) Regulators of $G$ protein signaling are up-regulated in aspirin-resistant platelets from patients with metabolic syndrome. Pharmazie 69: 371-3 [PMID:24855830]

310. Martemyanov KA, Yoo PJ, Skiba NP and Arshavsky VY. (2005) R7BP, a novel neuronal protein interacting with RGS proteins of the R7 family. J. Biol. Chem. 280: 5133-6 [PMID:15632198]

311. Martin-McCaffrey L, Hains MD, Pritchard GA, Pajak A, Dagnino L, Siderovski DP and D'Souza SJ. (2005) Differential expression of regulator of G-protein signaling R12 subfamily members during mouse development. Dev. Dyn. 234: 438-44 [PMID:16145674]

312. Martin-McCaffrey L, Willard FS, Oliveira-dos-Santos AJ, Natale DR, Snow BE, Kimple RJ, Pajak A, Watson AJ, Dagnino L and Penninger JM et al.. (2004) RGS14 is a mitotic spindle protein essential from the first division of the mammalian zygote. Dev. Cell 7: 763-9 [PMID:15525537]

313. Martín-Montañez E, Acevedo MJ, López-Téllez JF, Duncan RS, Mateos AG, Pavía J, Koulen P and Khan ZU. (2010) Regulator of G-protein signaling 14 protein modulates $\mathrm{Ca}^{2}+$ influx through Cav1 channels. Neuroreport 21: 1034-9 [PMID:20842066]

314. Masuho I, Celver J, Kovoor A and Martemyanov KA. (2010) Membrane anchor R9AP potentiates GTPaseaccelerating protein activity of RGS11 x Gbeta5 complex and accelerates inactivation of the mGluR6-G(o) signaling. J. Biol. Chem. 285: 4781-7 [PMID:20007977]

315. Masuho I, Itoh M, Itoh H and Saitoh O. (2004) The mechanism of membrane-translocation of regulator of G-protein signaling (RGS) 8 induced by Galpha expression. J. Neurochem. 88: 161-8 [PMID:14675160]

316. Masuho I, Xie K and Martemyanov KA. (2013) Macromolecular composition dictates receptor and G protein selectivity of regulator of G protein signaling (RGS) 7 and 9-2 protein complexes in living cells. $J$. Biol. Chem. 288: 25129-42 [PMID:23857581]

317. Melliti K, Meza U, Fisher R and Adams B. (1999) Regulators of $G$ protein signaling attenuate the $G$ protein-mediated inhibition of N-type Ca channels. J. Gen. Physiol. 113: 97-110 [PMID:9874691]

318. Meyer G, Varoqueaux F, Neeb A, Oschlies M and Brose N. (2004) The complexity of PDZ domainmediated interactions at glutamatergic synapses: a case study on neuroligin. Neuropharmacology 47: 72433 [PMID:15458844]

319. Mhawech P. (2005) 14-3-3 proteins--an update.Cell Res. 15: 228-36 [PMID:15857577]

320. Miao R, Lu Y, Xing X, Li Y, Huang Z, Zhong H, Huang Y, Chen AF, Tang X and Li łt al.. (2016) Regulator of G-Protein Signaling 10 Negatively Regulates Cardiac Remodeling by Blocking MitogenActivated Protein Kinase-Extracellular Signal-Regulated Protein Kinase 1/2 Signaling. Hypertension 67: 86-98 [PMID:26573707]

321. Michaelides M, Li Z, Rana NA, Richardson EC, Hykin PG, Moore AT, Holder GE and Webster AR. (2010) Novel mutations and electrophysiologic findings in RGS9- and R9AP-associated retinal dysfunction (Bradyopsia). Ophthalmology 117: 120-127.e1 [PMID:19818506]

322. Miles RR, Sluka JP, Santerre RF, Hale LV, Bloem L, Boguslawski G, Thirunavukkarasu K, Hock JM and Onyia JE. (2000) Dynamic regulation of RGS2 in bone: potential new insights into parathyroid hormone signaling mechanisms. Endocrinology 141: 28-36 [PMID:10614620]

323. Mirnics K, Middleton FA, Stanwood GD, Lewis DA and Levitt P. (2001) Disease-specific changes in regulator of G-protein signaling 4 (RGS4) expression in schizophrenia. Mol. Psychiatry 6: 293-301 [PMID:11326297]

324. Mitchell TS, Bradley J, Robinson GS, Shima DT and Ng YS. (2008) RGS5 expression is a quantitative 
measure of pericyte coverage of blood vessels. Angiogenesis 11: 141-51 [PMID:18038251]

325. Mittal V and Linder ME. (2004) The RGS14 GoLoco domain discriminates among Galphai isoformsJ. Biol. Chem. 279: 46772-8 [PMID:15337739]

326. Mittal V and Linder ME. (2006) Biochemical characterization of RGS14: RGS14 activity towards G-protein alpha subunits is independent of its binding to Rap2A. Biochem. J. 394: 309-15 [PMID:16246175]

327. Mittmann C, Chung CH, Höppner G, Michalek C, Nose M, Schüler C, Schuh A, Eschenhagen T, Weil J and Pieske B et al.. (2002) Expression of ten RGS proteins in human myocardium: functional characterization of an upregulation of RGS4 in heart failure. Cardiovasc. Res. 55: 778-86 [PMID:12176127]

328. Mittmann C, Schüler C, Chung CH, Höppner G, Nose M, Kehrl JH and Wieland T. (2001) Evidence for a short form of RGS3 preferentially expressed in the human heart. Naunyn Schmiedebergs Arch. Pharmacol. 363: 456-63 [PMID:11330340]

329. Miyamoto-Matsubara M, Chung $S$ and Saito Y. (2010) Functional interaction of regulator of $G$ protein signaling-2 with melanin-concentrating hormone receptor 1. Ann. N. Y. Acad. Sci. 1200: 112-9 [PMID:20633139]

330. Miyamoto-Matsubara M, Saitoh O, Maruyama K, Aizaki Y and Saito Y. (2008) Regulation of melaninconcentrating hormone receptor 1 signaling by RGS8 with the receptor third intracellular loop. Cell. Signal. 20: 2084-94 [PMID:18760349]

331. Miyoshi N, Ishii H, Sekimoto M, Doki Y and Mori M. (2009) RGS16 is a marker for prognosis in colorectal cancer. Ann. Surg. Oncol. 16: 3507-14 [PMID:19760045]

332. Mojumder DK, Qian Y and Wensel TG. (2009) Two R7 regulator of G-protein signaling proteins shape retinal bipolar cell signaling. J. Neurosci. 29: 7753-65 [PMID:19535587]

333. Monroy CA, Mackie DI and Roman DL. (2013) A high throughput screen for RGS proteins using steady state monitoring of free phosphate formation. PLOS ONE 8: e62247 [PMID:23626793]

334. Moratz C, Harrison K and Kehrl JH. (2004) Regulation of chemokine-induced lymphocyte migration by RGS proteins. Meth. Enzymol. 389: 15-32 [PMID:15313557]

335. Moratz C, Hayman JR, Gu H and Kehrl JH. (2004) Abnormal B-cell responses to chemokines, disturbed plasma cell localization, and distorted immune tissue architecture in Rgs1-/- mice. Mol. Cell. Biol. 24: 576775 [PMID:15199133]

336. Moratz C, Kang VH, Druey KM, Shi CS, Scheschonka A, Murphy PM, Kozasa T and Kehrl JH. (2000) Regulator of $\mathrm{G}$ protein signaling 1 (RGS1) markedly impairs Gi alpha signaling responses of $\mathrm{B}$ lymphocytes. J. Immunol. 164: 1829-38 [PMID:10657631]

337. Morris DW, Rodgers A, McGhee KA, Schwaiger S, Scully P, Quinn J, Meagher D, Waddington JL, Gill M and Corvin AP. (2004) Confirming RGS4 as a susceptibility gene for schizophrenia. Am. J. Med. Genet. B Neuropsychiatr. Genet. 125B: 50-3 [PMID:14755443]

338. Mouri K, Hishimoto A, Fukutake M, Nishiguchi N, Shirakawa O and Maeda K. (2010) Association study of RGS2 gene polymorphisms with panic disorder in Japanese. Kobe J Med Sci55: E116-21 [PMID:20847599]

339. Mowry EM, Carey RF, Blasco MR, Pelletier J, Duquette P, Villoslada P, Malikova I, Roger E, Kinkel RP and McDonald J et al.. (2013) Multiple sclerosis susceptibility genes: associations with relapse severity and recovery. PLOS ONE 8: e75416 [PMID:24130709]

340. Muntean BS, Patil DN, Madoux F, Fossetta J, Scampavia L, Spicer TP and Martemyanov KA. (2018) A High-Throughput Time-Resolved Fluorescence Energy Transfer Assay to Screen for Modulators of RGS7/Gß5/R7BP Complex. Assay Drug Dev Technol 16: 150-161 [PMID:29658790]

341. Murphy JJ and Norton JD. (1993) Multiple signaling pathways mediate anti-lg and IL-4-induced early response gene expression in human tonsillar B cells. Eur. J. Immunol. 23: 2876-81 [PMID:7693480]

342. Nagata Y, Oda M, Nakata H, Shozaki Y, Kozasa T and Todokoro K. (2001) A novel regulator of G-protein signaling bearing GAP activity for Galphai and Galphaq in megakaryocytes. Blood 97: 3051-60 [PMID:11342430]

343. Natochin M, Lipkin VM and Artemyev NO. (1997) Interaction of human retinal RGS with G-protein alphasubunits. FEBS Lett. 411: 179-82 [PMID:9271201]

344. Neill JD, Duck LW, Sellers JC, Musgrove LC, Scheschonka A, Druey KM and Kehrl JH. (1997) Potential role for a regulator of $G$ protein signaling (RGS3) in gonadotropin-releasing hormone $(\mathrm{GnRH})$ stimulated desensitization. Endocrinology 138: 843-6 [PMID:9003025]

345. Neubig RR and Siderovski DP. (2002) Regulators of G-protein signalling as new central nervous system drug targets. Nat Rev Drug Discov 1: 187-97 [PMID:12120503]

346. Neuillé M, Morgans CW, Cao Y, Orhan E, Michiels C, Sahel JA, Audo I, Duvoisin RM, Martemyanov KA and Zeitz C. (2015) LRIT3 is essential to localize TRPM1 to the dendritic tips of depolarizing bipolar cells and may play a role in cone synapse formation. Eur. J. Neurosci. 42: 1966-75 [PMID:25997951]

347. Newton JS, Deed RW, Mitchell EL, Murphy JJ and Norton JD. (1993) A B cell specific immediate early human gene is located on chromosome band $1 \mathrm{q} 31$ and encodes an alpha helical basic phosphoprotein. Biochim. Biophys. Acta 1216: 314-6 [PMID:8241276]

348. Nguyen $\mathrm{CH}$, Ming H, Zhao P, Hugendubler L, Gros R, Kimball SR and Chidiac P. (2009) Translational control by RGS2. J. Cell Biol. 186: 755-65 [PMID:19736320]

349. Nini L, Zhang JH, Pandey M, Panicker LM and Simonds WF. (2012) Expression of the GB5/R7-RGS protein complex in pituitary and pancreatic islet cells. Endocrine 42: 214-7 [PMID:22322946]

350. Nisancioglu MH, Mahoney Jr WM, Kimmel DD, Schwartz SM, Betsholtz C and Genové G. (2008) Generation and characterization of rgs5 mutant mice. Mol. Cell. Biol. 28: 2324-31 [PMID:18212066]

351. Nishiguchi KM, Sandberg MA, Kooijman AC, Martemyanov KA, Pott JW, Hagstrom SA, Arshavsky VY, 
Berson EL and Dryja TP. (2004) Defects in RGS9 or its anchor protein R9AP in patients with slow photoreceptor deactivation. Nature 427: 75-8 [PMID:14702087]

352. Nishiura H, Nonaka H, Revollo IS, Semba U, Li Y, Ota Y, Irie A, Harada K, Kehrl JH and Yamamoto T. (2009) Pro- and anti-apoptotic dual functions of the C5a receptor: involvement of regulator of $G$ protein signaling 3 and extracellular signal-regulated kinase. Lab. Invest. 89: 676-94 [PMID:19333232]

353. Nixon AB, Grenningloh $G$ and Casey PJ. (2002) The interaction of RGSZ1 with SCG10 attenuates the ability of SCG10 to promote microtubule disassembly. J. Biol. Chem. 277: 18127-33 [PMID:11882662]

354. Nolte IM, Munoz ML, Tragante V, Amare AT, Jansen R, Vaez A, von der Heyde B, Avery CL, Bis JC and Dierckx B et al.. (2017) Genetic loci associated with heart rate variability and their effects on cardiac disease risk. Nat Commun 8: 15805 [PMID:28613276]

355. Norlin EM and Berghard A. (2001) Spatially restricted expression of regulators of G-protein signaling in primary olfactory neurons. Mol. Cell. Neurosci. 17: 872-82 [PMID:11358484]

356. Nunn C, Zou MX, Sobiesiak AJ, Roy AA, Kirshenbaum LA and Chidiac P. (2010) RGS2 inhibits betaadrenergic receptor-induced cardiomyocyte hypertrophy. Cell. Signal. 22: 1231-9 [PMID:20362664]

357. O'Brien M, Morrison JJ and Smith TJ. (2008) Upregulation of PSCDBP, TLR2, TWIST1, FLJ35382, EDNRB, and RGS12 gene expression in human myometrium at labor. Reprod Sci 15: 382-93 [PMID:18497345]

358. Obsilova V, Kopecka M, Kosek D, Kacirova M, Kylarova S, Rezabkova L and Obsil T. (2014) Mechanisms of the 14-3-3 protein function: regulation of protein function through conformational modulation. Physiol Res 63 Suppl 1: S155-64 [PMID:24564655]

359. Ocal O, Pashkov V, Kollipara RK, Zolghadri Y, Cruz VH, Hale MA, Heath BR, Artyukhin AB, Christie AL and Tsoulfas $P$ et al.. (2015) A rapid in vivo screen for pancreatic ductal adenocarcinoma therapeutics.Dis Model Mech 8: 1201-11 [PMID:26438693]

360. Ohi K, Shimada T, Nitta Y, Kihara H, Okubo H, Uehara T and Kawasaki Y. (2016) Specific gene expression patterns of 108 schizophrenia-associated loci in cortex. Schizophr. Res. 174: 35-38 [PMID:27061659]

361. Oliveira-Dos-Santos AJ, Matsumoto G, Snow BE, Bai D, Houston FP, Whishaw IQ, Mariathasan S, Sasaki T, Wakeham A and Ohashi PS et al.. (2000) Regulation of T cell activation, anxiety, and male aggression by RGS2. Proc. Natl. Acad. Sci. U.S.A. 97: 12272-7 [PMID:11027316]

362. Oláh J, Vincze O, Virók D, Simon D, Bozsó Z, Tõkési N, Horváth I, Hlavanda E, Kovács J and Magyar ßet al.. (2011) Interactions of pathological hallmark proteins: tubulin polymerization promoting protein/p25, beta-amyloid, and alpha-synuclein. J. Biol. Chem. 286: 34088-100 [PMID:21832049]

363. Ooe A, Kato K and Noguchi S. (2007) Possible involvement of CCT5, RGS3, and YKT6 genes upregulated in p53-mutated tumors in resistance to docetaxel in human breast cancers. Breast Cancer Res. Treat. 101: 305-15 [PMID:16821082]

364. Opel A, Nobles M, Montaigne D, Finlay M, Anderson N, Breckenridge R and Tinker A. (2015) Absence of the Regulator of G-protein Signaling, RGS4, Predisposes to Atrial Fibrillation and Is Associated with Abnormal Calcium Handling. J. Biol. Chem. 290: 19233-44 [PMID:26088132]

365. Orlandi C, Posokhova E, Masuho I, Ray TA, Hasan N, Gregg RG and Martemyanov KA. (2012) GPR158/179 regulate $G$ protein signaling by controlling localization and activity of the RGS7 complexes. J. Cell Biol. 197: 711-9 [PMID:22689652]

366. Orlandi C, Sutton LP, Muntean BS, Song C and Martemyanov KA. (2019) Homeostatic cAMP regulation by the RGS7 complex controls depression-related behaviors. Neuropsychopharmacology 44: 642-653 [PMID:30546127]

367. Osei-Owusu P, Sun X, Drenan RM, Steinberg TH and Blumer KJ. (2007) Regulation of RGS2 and second messenger signaling in vascular smooth muscle cells by cGMP-dependent protein kinase. J. Biol. Chem. 282: 31656-65 [PMID:17681944]

368. Ostrovskaya O, Xie K, Masuho I, Fajardo-Serrano A, Lujan R, Wickman K and Martemyanov KA. (2014) RGS7/GB5/R7BP complex regulates synaptic plasticity and memory by modulating hippocampal GABABR-GIRK signaling. Elife 3: e02053 [PMID:24755289]

369. Ostrovskaya OI, Orlandi C, Fajardo-Serrano A, Young Jr SM, Lujan R and Martemyanov KA. (2018) Inhibitory Signaling to Ion Channels in Hippocampal Neurons Is Differentially Regulated by Alternative Macromolecular Complexes of RGS7. J. Neurosci. 38: 10002-10015 [PMID:30315127]

370. Otowa T, Shimada T, Kawamura Y, Sugaya N, Yoshida E, Inoue K, Yasuda S, Liu X, Minato T and Tochigi M et al.. (2011) Association of RGS2 variants with panic disorder in a Japanese population Am. J. Med. Genet. B Neuropsychiatr. Genet. 156B: 430-4 [PMID:21438143]

371. Pak HK, Gil M, Lee Y, Lee H, Lee AN, Roh J and Park CS. (2015) Regulator of G protein signaling 1 suppresses CXCL12-mediated migration and AKT activation in RPMI 8226 human plasmacytoma cells and plasmablasts. PLoS ONE 10: e0124793 [PMID:25897806]

372. Park IK, Klug CA, Li K, Jerabek L, Li L, Nanamori M, Neubig RR, Hood L, Weissman IL and Clarke MF. (2001) Molecular cloning and characterization of a novel regulator of G-protein signaling from mouse hematopoietic stem cells. J. Biol. Chem. 276: 915-23 [PMID:11042171]

373. Park-Windhol C, Zhang P, Zhu M, Su J, Chaves Jr L, Maldonado AE, King ME, Rickey L, Cullen D and Mende U. (2012) Gq/11-mediated signaling and hypertrophy in mice with cardiac-specific transgenic expression of regulator of G-protein signaling 2. PLOS ONE 7: e40048 [PMID:22802950]

374. Pashkov V, Huang J, Parameswara VK, Kedzierski W, Kurrasch DM, Tall GG, Esser V, Gerard RD, Uyeda $\mathrm{K}$ and Towle HC et al.. (2011) Regulator of G protein signaling (RGS16) inhibits hepatic fatty acid oxidation 
in a carbohydrate response element-binding protein (ChREBP)-dependent manner. J. Biol. Chem. 286: 15116-25 [PMID:21357625]

375. Patel J, Channon KM and McNeill E. (2013) The downstream regulation of chemokine receptor signalling: implications for atherosclerosis. Mediators Inflamm. 2013: 459520 [PMID:23690662]

376. Patel J, McNeill E, Douglas G, Hale AB, de Bono J, Lee R, Iqbal AJ, Regan-Komito D, Stylianou E and Greaves DR et al.. (2015) RGS1 regulates myeloid cell accumulation in atherosclerosis and aortic aneurysm rupture through altered chemokine signalling. Nat Commun 6: 6614 [PMID:25782711]

377. Patil DN, Rangarajan ES, Novick SJ, Pascal BD, Kojetin DJ, Griffin PR, Izard T and Martemyanov KA. (2018) Structural organization of a major neuronal G protein regulator, the RGS7-G $\beta 5-R 7 B P$ complex. Elife 7: e42150 [PMID:30540250]

378. Patten M, Krämer E, Bünemann J, Wenck C, Thoenes M, Wieland T and Long C. (2001) Endotoxin and cytokines alter contractile protein expression in cardiac myocytes in vivo. Pflugers Arch. 442: 920-7 [PMID:11680626]

379. Patten M, Stübe S, Thoma B and Wieland T. (2003) Interleukin-1beta mediates endotoxin- and tumor necrosis factor alpha-induced RGS16 protein expression in cultured cardiac myocytes. Naunyn Schmiedebergs Arch. Pharmacol. 368: 360-5 [PMID:14566449]

380. Plaza-Izurieta L, Castellanos-Rubio A, Irastorza I, Fernández-Jimenez N, Gutierrez G, CEGEC and Bilbao JR. (2011) Revisiting genome wide association studies (GWAS) in coeliac disease: replication study in Spanish population and expression analysis of candidate genes. J. Med. Genet. 48: 493-6 [PMID:21490378]

381. Popov SG, Krishna UM, Falck JR and Wilkie TM. (2000) Ca2+/Calmodulin reverses phosphatidylinositol 3,4, 5-trisphosphate-dependent inhibition of regulators of $\mathrm{G}$ protein-signaling GTPase-activating protein activity. J. Biol. Chem. 275: 18962-8 [PMID:10747990]

382. Posner BA, Gilman AG and Harris BA. (1999) Regulators of G protein signaling 6 and 7. Purification of complexes with gbeta5 and assessment of their effects on g protein-mediated signaling pathways. J. Biol. Chem. 274: 31087-93 [PMID:10521509]

383. Posokhova E, Uversky V and Martemyanov KA. (2010) Proteomic identification of Hsc70 as a mediator of RGS9-2 degradation by in vivo interactome analysis. J. Proteome Res. 9: 1510-21 [PMID:20095651]

384. Posokhova E, Wydeven N, Allen KL, Wickman K and Martemyanov KA. (2010) RGS6/G $\beta 5$ complex accelerates IKACh gating kinetics in atrial myocytes and modulates parasympathetic regulation of heart rate. Circ. Res. 107: 1350-4 [PMID:20884879]

385. Potocnik U, Glavac D and Ravnik-Glavac M. (2003) Identification of novel genes with somatic frameshift mutations within coding mononucleotide repeats in colorectal tumors with high microsatellite instability. Genes Chromosomes Cancer 36: 48-56 [PMID:12461749]

386. Psifogeorgou K, Papakosta P, Russo SJ, Neve RL, Kardassis D, Gold SJ and Zachariou V. (2007) RGS92 is a negative modulator of mu-opioid receptor function. J. Neurochem. 103: 617-25 [PMID:17725581]

387. Qin M, Huang H, Wang T, Hu H, Liu Y, Cao H, Li H and Huang C. (2012) Absence of Rgs5 prolongs cardiac repolarization and predisposes to ventricular tachyarrhythmia in mice. J. Mol. Cell. Cardiol.53: 880-90 [PMID:23079193]

388. Qin M, Huang H, Wang T, Hu H, Liu Y, Gu Y, Cao H, Li H and Huang C. (2012) Atrial tachyarrhythmia in Rgs5-null mice. PLoS ONE 7: e46856 [PMID:23144791]

389. Qiu R, Wang J, Tsark W and Lu Q. (2010) Essential role of PDZ-RGS3 in the maintenance of neural progenitor cells. Stem Cells 28: 1602-10 [PMID:20629178]

390. Qutob N, Masuho I, Alon M, Emmanuel R, Cohen I, Di Pizio A, Madore J, Elkahloun A, Ziv T and Levy Ret al.. (2018) RGS7 is recurrently mutated in melanoma and promotes migration and invasion of human cancer cells. Sci Rep 8: 653 [PMID:29330521]

391. Raab RM, Bullen J, Kelleher J, Mantzoros C and Stephanopoulos G. (2005) Regulation of mouse hepatic genes in response to diet induced obesity, insulin resistance and fasting induced weight reduction. Nutr Metab (Lond) 2: 15 [PMID:15985155]

392. Raedler D, Ballenberger N, Klucker E, Böck A, Otto R, Prazeres da Costa O, Holst O, Illig T, Buch T and von Mutius $\mathrm{E}$ et al.. (2015) Identification of novel immune phenotypes for allergic and nonallergic childhood asthma. J. Allergy Clin. Immunol. 135: 81-91 [PMID:25226851]

393. Rahman Z, Gold SJ, Potenza MN, Cowan CW, Ni YG, He W, Wensel TG and Nestler EJ. (1999) Cloning and characterization of RGS9-2: a striatal-enriched alternatively spliced product of the RGS9 gene. J. Neurosci. 19: 2016-26 [PMID:10066255]

394. Rahman Z, Schwarz J, Gold SJ, Zachariou V, Wein MN, Choi KH, Kovoor A, Chen CK, DiLeone RJ and Schwarz SC et al.. (2003) RGS9 modulates dopamine signaling in the basal ganglia.Neuron 38: 941-52 [PMID:12818179]

395. Raveh A, Schultz PJ, Aschermann L, Carpenter C, Tamayo-Castillo G, Cao S, Clardy J, Neubig RR, Sherman DH and Sjögren B. (2014) Identification of protein kinase C activation as a novel mechanism for RGS2 protein upregulation through phenotypic screening of natural product extracts. Mol. Pharmacol. 86: 406-16 [PMID:25086086]

396. Reif K and Cyster JG. (2000) RGS molecule expression in murine B lymphocytes and ability to downregulate chemotaxis to lymphoid chemokines. J. Immunol. 164: 4720-9 [PMID:10779778]

397. Rezabkova L, Boura E, Herman P, Vecer J, Bourova L, Sulc M, Svoboda P, Obsilova V and Obsil T. (2010) 14-3-3 protein interacts with and affects the structure of RGS domain of regulator of $G$ protein signaling 3 (RGS3). J. Struct. Biol. 170: 451-61 [PMID:20347994]

398. Richman RW and Diversé-Pierluissi MA. (2004) Mapping of RGS12-Cav2.2 channel interaction.Meth. 
Enzymol. 390: 224-39 [PMID:15488181]

399. Richman RW, Strock J, Hains MD, Cabanilla NJ, Lau KK, Siderovski DP and Diversé-Pierluissi M. (2005) RGS12 interacts with the SNARE-binding region of the Cav2.2 calcium channel. J. Biol. Chem. 280: 15218 [PMID:15536086]

400. Riddle EL, Rana BK, Murthy KK, Rao F, Eskin E, O'Connor DT and Insel PA. (2006) Polymorphisms and haplotypes of the regulator of $\mathrm{G}$ protein signaling-2 gene in normotensives and hypertensives. Hypertension 47: 415-20 [PMID:16432041]

401. Riddle EL, Schwartzman RA, Bond M and Insel PA. (2005) Multi-tasking RGS proteins in the heart: the next therapeutic target? Circ. Res. 96: 401-11 [PMID:15746448]

402. Riekenberg S, Farhat K, Debarry J, Heine H, Jung G, Wiesmüller KH and Ulmer AJ. (2009) Regulators of G-protein signalling are modulated by bacterial lipopeptides and lipopolysaccharide. FEBS J 276: 649-59 [PMID:19120454]

403. Rolland T, Taşan M, Charloteaux B, Pevzner SJ, Zhong Q, Sahni N, Yi S, Lemmens I, Fontanillo C and Mosca R et al.. (2014) A proteome-scale map of the human interactome network.Cell 159: 1212-26 [PMID:25416956]

404. Roman DL, Blazer LL, Monroy CA and Neubig RR. (2010) Allosteric inhibition of the regulator of G protein signaling-Galpha protein-protein interaction by CCG-4986. Mol. Pharmacol. 78: 360-5 [PMID:20530129]

405. Roman DL, Talbot JN, Roof RA, Sunahara RK, Traynor JR and Neubig RR. (2007) Identification of smallmolecule inhibitors of RGS4 using a high-throughput flow cytometry protein interaction assay. Mol. Pharmacol. 71: 169-75 [PMID:17012620]

406. Romanos J, Barisani D, Trynka G, Zhernakova A, Bardella MT and Wijmenga C. (2009) Six new coeliac disease loci replicated in an Italian population confirm association with coeliac disease. J. Med. Genet. 46: 60-3 [PMID:18805825]

407. Roof RA, Jin Y, Roman DL, Sunahara RK, Ishii M, Mosberg HI and Neubig RR. (2006) Mechanism of action and structural requirements of constrained peptide inhibitors of RGS proteins. Chem Biol Drug Des 67: 266-74 [PMID:16629824]

408. Roof RA, Roman DL, Clements ST, Sobczyk-Kojiro K, Blazer LL, Ota S, Mosberg HI and Neubig RR. (2009) A covalent peptide inhibitor of RGS4 identified in a focused one-bead, one compound library screen. BMC Pharmacol. 9: 9 [PMID:19463173]

409. Rorabaugh BR, Chakravarti B, Mabe NW, Seeley SL, Bui AD, Yang J, Watts SW, Neubig RR and Fisher RA. (2017) Regulator of G Protein Signaling 6 Protects the Heart from Ischemic Injury. J. Pharmacol. Exp. Ther. 360: 409-416 [PMID:28035008]

410. Rose JJ, Taylor JB, Shi J, Cockett MI, Jones PG and Hepler JR. (2000) RGS7 is palmitoylated and exists as biochemically distinct forms. J. Neurochem. 75: 2103-12 [PMID:11032900]

411. Ross EM and Wilkie TM. (2000) GTPase-activating proteins for heterotrimeric G proteins: regulators of $G$ protein signaling (RGS) and RGS-like proteins. Annu. Rev. Biochem. 69: 795-827 [PMID:10966476]

412. Roy AA, Baragli A, Bernstein LS, Hepler JR, Hébert TE and Chidiac P. (2006) RGS2 interacts with Gs and adenylyl cyclase in living cells. Cell. Signal. 18: 336-48 [PMID:16095880]

413. Roy AA, Nunn C, Ming H, Zou MX, Penninger J, Kirshenbaum LA, Dixon SJ and Chidiac P. (2006) Upregulation of endogenous RGS2 mediates cross-desensitization between Gs and Gq signaling in osteoblasts. J. Biol. Chem. 281: 32684-93 [PMID:16950788]

414. Ruiz de Azua I, Scarselli M, Rosemond E, Gautam D, Jou W, Gavrilova O, Ebert PJ, Levitt P and Wess J. (2010) RGS4 is a negative regulator of insulin release from pancreatic beta-cells in vitro and in vivo. Proc. Natl. Acad. Sci. U.S.A. 107: 7999-8004 [PMID:20385802]

415. Saitoh O, Kubo Y, Miyatani Y, Asano T and Nakata H. (1997) RGS8 accelerates G-protein-mediated modulation of K+ currents. Nature 390: 525-9 [PMID:9394004]

416. Saitoh O, Kubo Y, Odagiri M, Ichikawa M, Yamagata K and Sekine T. (1999) RGS7 and RGS8 differentially accelerate $G$ protein-mediated modulation of $K+$ currents. J. Biol. Chem. 274: 9899-904 [PMID:10092682]

417. Saitoh O, Masuho I, Itoh M, Abe H, Komori K and Odagiri M. (2003) Distribution of regulator of G protein signaling 8 (RGS8) protein in the cerebellum. Cerebellum 2: 154-60 [PMID:12880183]

418. Saitoh O, Masuho I, Terakawa I, Nomoto S, Asano T and Kubo Y. (2001) Regulator of G protein signaling 8 (RGS8) requires its $\mathrm{NH} 2$ terminus for subcellular localization and acute desensitization of $\mathrm{G}$ proteingated K+ channels. J. Biol. Chem. 276: 5052-8 [PMID:11087736]

419. Saitoh O, Murata Y, Odagiri M, Itoh M, Itoh H, Misaka T and Kubo Y. (2002) Alternative splicing of RGS8 gene determines inhibitory function of receptor type-specific $\mathrm{Gq}$ signaling. Proc. Natl. Acad. Sci. U.S.A. 99: 10138-43 [PMID:12110731]

420. Saitoh O and Odagiri M. (2003) RGS8 expression in developing cerebellar Purkinje cells Biochem. Biophys. Res. Commun. 309: 836-42 [PMID:13679049]

421. Saitoh O and Yoshihiro K. (2004) Biochemical and electrophysiological analyses of RGS8 function.Meth. Enzymol. 390: 129-48 [PMID:15488175]

422. Saleem Y and Kim KS. (2009) RGS11 interacts preferentially with R7BP over Galpha(oa)--characterization of Gbeta5-free RGS11. Biochem. Biophys. Res. Commun. 386: 65-70 [PMID:19497306]

423. Salim S, Sinnarajah S, Kehrl JH and Dessauer CW. (2003) Identification of RGS2 and type V adenylyl cyclase interaction sites. J. Biol. Chem. 278: 15842-9 [PMID:12604604]

424. Sambi BS, Hains MD, Waters CM, Connell MC, Willard FS, Kimple AJ, Pyne S, Siderovski DP and Pyne NJ. (2006) The effect of RGS12 on PDGFbeta receptor signalling to p42/p44 mitogen activated protein 
kinase in mammalian cells. Cell. Signal. 18: 971-81 [PMID:16214305]

425. Sandiford SL and Slepak VZ. (2009) The Gbeta5-RGS7 complex selectively inhibits muscarinic M3 receptor signaling via the interaction between the third intracellular loop of the receptor and the DEP domain of RGS7. Biochemistry 48: 2282-9 [PMID:19182865]

426. Sarria I, Orlandi C, McCall MA, Gregg RG and Martemyanov KA. (2016) Intermolecular Interaction between Anchoring Subunits Specify Subcellular Targeting and Function of RGS Proteins in Retina ONBipolar Neurons. J. Neurosci. 36: 2915-25 [PMID:26961947]

427. Sato J, Kimura T, Saito T, Anazawa T, Kenjo A, Sato Y, Tsuchiya T and Gotoh M. (2011) Gene expression analysis for predicting gemcitabine resistance in human cholangiocarcinoma. J Hepatobiliary Pancreat Sci 18: 700-11 [PMID:21451941]

428. Scacheri PC, Crabtree JS, Novotny EA, Garrett-Beal L, Chen A, Edgemon KA, Marx SJ, Spiegel AM, Chandrasekharappa SC and Collins FS. (2001) Bidirectional transcriptional activity of PGK-neomycin and unexpected embryonic lethality in heterozygote chimeric knockout mice. Genesis 30: 259-63 [PMID:11536432]

429. Scheschonka A, Dessauer CW, Sinnarajah S, Chidiac P, Shi CS and Kehrl JH. (2000) RGS3 is a GTPase-activating protein for $\mathrm{g}$ (ialpha) and $\mathrm{g}$ (qalpha) and a potent inhibitor of signaling by GTPasedeficient forms of g(qalpha) and g(11alpha). Mol. Pharmacol. 58: 719-28 [PMID:10999941]

430. Schiff ML, Siderovski DP, Jordan JD, Brothers G, Snow B, De Vries L, Ortiz DF and Diversé-Pierluissi M. (2000) Tyrosine-kinase-dependent recruitment of RGS12 to the N-type calcium channel. Nature 408: 7237 [PMID:11130074]

431. Schoeber JP, Topala CN, Wang X, Diepens RJ, Lambers TT, Hoenderop JG and Bindels RJ. (2006) RGS2 inhibits the epithelial Ca2+ channel TRPV6. J. Biol. Chem. 281: 29669-74 [PMID:16895908]

432. Schroer AB, Mohamed JS, Willard MD, Setola V, Oestreich E and Siderovski DP. (2019) A role for Regulator of $G$ protein Signaling-12 (RGS12) in the balance between myoblast proliferation and differentiation. PLoS One 14: e0216167 [PMID:31408461]

433. Segers I, Adriaenssens T and Smitz J. (2012) Expression patterns of poliovirus receptor, erythrocyte protein band 4.1-like 3, regulator of g-protein signaling 11, and oxytocin receptor in mouse ovarian cells during follicle growth and early luteinization in vitro and in vivo. Biol. Reprod. 86: 1-11 [PMID:21957189]

434. Seki N, Hattori A, Hayashi A, Kozuma S, Hori T and Saito T. (1999) The human regulator of G-protein signaling protein 6 gene (RGS6) maps between markers WI-5202 and D14S277 on chromosome 14q24.3. J. Hum. Genet. 44: 138-40 [PMID:10083744]

435. Seki N, Sugano S, Suzuki Y, Nakagawara A, Ohira M, Muramatsu M, Saito T and Hori T. (1998) Isolation, tissue expression, and chromosomal assignment of human RGS5, a novel G-protein signaling regulator gene. J. Hum. Genet. 43: 202-5 [PMID:9747037]

436. Semplicini A, Lenzini L, Sartori M, Papparella I, Calò LA, Pagnin E, Strapazzon G, Benna C, Costa R and Avogaro A et al.. (2006) Reduced expression of regulator of G-protein signaling 2 (RGS2) in hypertensive patients increases calcium mobilization and ERK1/2 phosphorylation induced by angiotensin II. J. Hypertens. 24: 1115-24 [PMID:16685212]

437. Seno K, Kishigami A, Ihara S, Maeda T, Bondarenko VA, Nishizawa Y, Usukura J, Yamazaki A and Hayashi F. (1998) A possible role of RGS9 in phototransduction. A bridge between the cGMPphosphodiesterase system and the guanylyl cyclase system. J. Biol. Chem. 273: 22169-72 [PMID:9712827]

438. Sethakorn N and Dulin NO. (2013) RGS expression in cancer: oncomining the cancer microarray data $J$. Recept. Signal Transduct. Res. 33: 166-71 [PMID:23464602]

439. Shi CS, Huang NN and Kehrl JH. (2012) Regulator of G-protein signaling 3 isoform 1 (PDZ-RGS3) enhances canonical Wnt signaling and promotes epithelial mesenchymal transition. J. Biol. Chem. 287: 33480-7 [PMID:22859293]

440. Shi GX, Harrison K, Han SB, Moratz C and Kehrl JH. (2004) Toll-like receptor signaling alters the expression of regulator of $\mathrm{G}$ protein signaling proteins in dendritic cells: implications for $\mathrm{G}$ protein-coupled receptor signaling. J. Immunol. 172: 5175-84 [PMID:15100254]

441. Shi GX, Harrison K, Wilson GL, Moratz C and Kehrl JH. (2002) RGS13 regulates germinal center B lymphocytes responsiveness to CXC chemokine ligand (CXCL)12 and CXCL13. J. Immunol. 169: 2507-15 [PMID:12193720]

442. Shim H, Wang CT, Chen YL, Chau VQ, Fu KG, Yang J, McQuiston AR, Fisher RA and Chen CK. (2012) Defective retinal depolarizing bipolar cells in regulators of $G$ protein signaling (RGS) 7 and 11 double null mice. J. Biol. Chem. 287: 14873-9 [PMID:22371490]

443. Shu FJ, Ramineni S, Amyot W and Hepler JR. (2007) Selective interactions between Gi alpha1 and Gi alpha3 and the GoLoco/GPR domain of RGS14 influence its dynamic subcellular localization. Cell. Signal. 19: 163-76 [PMID:16870394]

444. Shu FJ, Ramineni S and Hepler JR. (2010) RGS14 is a multifunctional scaffold that integrates G protein and Ras/Raf MAPkinase signalling pathways. Cell. Signal. 22: 366-76 [PMID:19878719]

445. Sibbel SP, Talbert ME, Bowden DW, Haffner SM, Taylor KD, Chen YD, Wagenknecht LE, Langefeld CD and Norris JM. (2011) RGS6 variants are associated with dietary fat intake in Hispanics: the IRAS Family Study. Obesity (Silver Spring) 19: 1433-8 [PMID:21233807]

446. Siderovski DP and Willard FS. (2005) The GAPs, GEFs, and GDIs of heterotrimeric G-protein alpha subunits. Int. J. Biol. Sci. 1: 51-66 [PMID:15951850]

447. Siedlecki A, Anderson JR, Jin X, Garbow JR, Lupu TS and Muslin AJ. (2010) RGS4 controls renal blood flow and inhibits cyclosporine-mediated nephrotoxicity. Am. J. Transplant. 10: 231-41 [PMID:19958325] 
448. Sierra DA, Gilbert DJ, Householder D, Grishin NV, Yu K, Ukidwe P, Barker SA, He W, Wensel TG and Otero $\mathrm{G}$ et al.. (2002) Evolution of the regulators of G-protein signaling multigene family in mouse and human. Genomics 79: 177-85 [PMID:11829488]

449. Silini A, Ghilardi C, Figini S, Sangalli F, Fruscio R, Dahse R, Pedley RB, Giavazzi R and Bani M. (2012) Regulator of G-protein signaling 5 (RGS5) protein: a novel marker of cancer vasculature elicited and sustained by the tumor's proangiogenic microenvironment. Cell. Mol. Life Sci. 69: 1167-78 [PMID:22130514]

450. Sjögren B. (2011) Regulator of $G$ protein signaling proteins as drug targets: current state and future possibilities. Adv. Pharmacol. 62: 315-47 [PMID:21907914]

451. Sjögren B, Blazer LL and Neubig RR. (2010) Regulators of $G$ protein signaling proteins as targets for drug discovery. Prog Mol Biol Transl Sci91: 81-119 [PMID:20691960]

452. Sjögren B, Parra S, Heath LJ, Atkins KB, Xie ZJ and Neubig RR. (2012) Cardiotonic steroids stabilize regulator of G protein signaling 2 protein levels. Mol. Pharmacol. 82: 500-9 [PMID:22695717]

453. Skarnes WC, Rosen B, West AP, Koutsourakis M, Bushell W, Iyer V, Mujica AO, Thomas M, Harrow J and Cox T et al.. (2011) A conditional knockout resource for the genome-wide study of mouse gene function. Nature 474: 337-42 [PMID:21677750]

454. Slep KC, Kercher MA, Wieland T, Chen CK, Simon MI and Sigler PB. (2008) Molecular architecture of Galphao and the structural basis for RGS16-mediated deactivation. Proc. Natl. Acad. Sci. U.S.A. 105: 6243-8 [PMID:18434540]

455. Slepak VZ. (2009) Structure, function, and localization of Gß5-RGS complexes.Prog Mol Biol Trans/ Sci 86: 157-203 [PMID:20374716]

456. Smoller JW, Paulus MP, Fagerness JA, Purcell S, Yamaki LH, Hirshfeld-Becker D, Biederman J, Rosenbaum JF, Gelernter J and Stein MB. (2008) Influence of RGS2 on anxiety-related temperament, personality, and brain function. Arch. Gen. Psychiatry 65: 298-308 [PMID:18316676]

457. Smyth DJ, Plagnol V, Walker NM, Cooper JD, Downes K, Yang JH, Howson JM, Stevens H, McManus R and Wijmenga $\mathrm{C}$ et al.. (2008) Shared and distinct genetic variants in type 1 diabetes and celiac disease. N. Engl. J. Med. 359: 2767-77 [PMID:19073967]

458. Snow BE, Antonio L, Suggs S, Gutstein HB and Siderovski DP. (1997) Molecular cloning and expression analysis of rat Rgs12 and Rgs14. Biochem. Biophys. Res. Commun. 233: 770-7 [PMID:9168931]

459. Snow BE, Antonio L, Suggs S and Siderovski DP. (1998) Cloning of a retinally abundant regulator of Gprotein signaling (RGS-r/RGS16): genomic structure and chromosomal localization of the human gene. Gene 206: 247-53 [PMID:9469939]

460. Snow BE, Brothers GM and Siderovski DP. (2002) Molecular cloning of regulators of G-protein signaling family members and characterization of binding specificity of RGS12 PDZ domain. Meth. Enzymol. 344: 740-61 [PMID:11771424]

461. Snow BE, Hall RA, Krumins AM, Brothers GM, Bouchard D, Brothers CA, Chung S, Mangion J, Gilman AG and Lefkowitz RJ et al.. (1998) GTPase activating specificity of RGS12 and binding specificity of an alternatively spliced PDZ (PSD-95/Dlg/ZO-1) domain. J. Biol. Chem. 273: 17749-55 [PMID:9651375]

462. Snow BE, Krumins AM, Brothers GM, Lee SF, Wall MA, Chung S, Mangion J, Arya S, Gilman AG and Siderovski DP. (1998) A G protein gamma subunit-like domain shared between RGS11 and other RGS proteins specifies binding to Gbeta5 subunits. Proc. Natl. Acad. Sci. U.S.A. 95: 13307-12 [PMID:9789084]

463. Song C, Anderson GR, Sutton LP, Dao M and Martemyanov KA. (2018) Selective Role of RGS9-2 in Regulating Retrograde Synaptic Signaling of Indirect Pathway Medium Spiny Neurons in Dorsal Striatum. J. Neurosci. 38: 7120-7131 [PMID:30006367]

464. Song C, Orlandi C, Sutton LP and Martemyanov KA. (2019) The signaling proteins GPR158 and RGS7 modulate excitability of L2/3 pyramidal neurons and control A-type potassium channel in the prelimbic cortex. J. Biol. Chem. 294: 13145-13157 [PMID:31311860]

465. Song JH, Song H, Wensel TG, Sokolov M and Martemyanov KA. (2007) Localization and differential interaction of R7 RGS proteins with their membrane anchors R7BP and R9AP in neurons of vertebrate retina. Mol. Cell. Neurosci. 35: 311-9 [PMID:17442586]

466. Song KS, Choi YH, Kim JM, Lee H, Lee TJ and Yoon JH. (2009) Suppression of prostaglandin E2-induced MUC5AC overproduction by RGS4 in the airway. Am. J. Physiol. Lung Cell Mol. Physiol. 296: L684-92 [PMID:19201815]

467. Sood R, Bonner TI, Makalowska I, Stephan DA, Robbins CM, Connors TD, Morgenbesser SD, Su K, Faruque MU and Pinkett $\mathrm{H}$ et al.. (2001) Cloning and characterization of 13 novel transcripts and the human RGS8 gene from the 1q25 region encompassing the hereditary prostate cancer (HPC1) locus. Genomics 73: 211-22 [PMID:11318611]

468. Soundararajan M, Willard FS, Kimple AJ, Turnbull AP, Ball LJ, Schoch GA, Gileadi C, Fedorov OY, Dowler EF and Higman VA et al.. (2008) Structural diversity in the RGS domain and its interaction with heterotrimeric G protein alpha-subunits. Proc. Natl. Acad. Sci. U.S.A. 105: 6457-62 [PMID:18434541]

469. Squires KE, Gerber KJ, Pare JF, Branch MR, Smith Y and Hepler JR. (2018) Regulator of G protein signaling 14 (RGS14) is expressed pre- and postsynaptically in neurons of hippocampus, basal ganglia, and amygdala of monkey and human brain. Brain Struct Funct 223: 233-253 [PMID:28776200]

470. Squires KE, Gerber KJ, Tillman MC, Lustberg DJ, Montañez-Miranda C, Zhao M, Ramineni S, Scharer CD, Shu F-j and Schroeder JP et al.. (2020) Human genetic variants disrupt RGS14 nuclear shuttling and regulation of LTP in hippocampal neurons bioRxiv

471. Stes E, Laga M, Walton A, Samyn N, Timmerman E, De Smet I, Goormachtig S and Gevaert K. (2014) A 
COFRADIC protocol to study protein ubiquitination. J. Proteome Res. 13: 3107-13 [PMID:24816145]

472. Stewart A, Maity B, Anderegg SP, Allamargot C, Yang J and Fisher RA. (2015) Regulator of G protein signaling 6 is a critical mediator of both reward-related behavioral and pathological responses to alcohol. Proc. Natl. Acad. Sci. U.S.A. 112: E786-95 [PMID:25646431]

473. Stewart A, Maity B, Wunsch AM, Meng F, Wu Q, Wemmie JA and Fisher RA. (2014) Regulator of Gprotein signaling 6 (RGS6) promotes anxiety and depression by attenuating serotonin-mediated activation of the 5-HT(1A) receptor-adenylyl cyclase axis. FASEB J. 28: 1735-44 [PMID:24421401]

474. Stiles JM, Rowntree RK, Amaya C, Diaz D, Kokta V, Mitchell DC and Bryan BA. (2013) Gene expression analysis reveals marked differences in the transcriptome of infantile hemangioma endothelial cells compared to normal dermal microvascular endothelial cells. Vasc Cell 5: 6 [PMID:23531100]

475. Storaska AJ, Mei JP, Wu M, Li M, Wade SM, Blazer LL, Sjögren B, Hopkins CR, Lindsley CW and Lin Zet al.. (2013) Reversible inhibitors of regulators of G-protein signaling identified in a high-throughput cellbased calcium signaling assay. Cell. Signal. 25: 2848-55 [PMID:24041654]

476. Strausberg RL, Feingold EA, Grouse LH, Derge JG, Klausner RD, Collins FS, Wagner L, Shenmen CM, Schuler GD and Altschul SF et al.. (2002) Generation and initial analysis of more than 15,000 full-length human and mouse cDNA sequences. Proc. Natl. Acad. Sci. U.S.A. 99: 16899-903 [PMID:12477932]

477. Stuebe S, Wieland T, Kraemer E, Stritzky Av, Schroeder D, Seekamp S, Vogt A, Chen CK and Patten M. (2008) Sphingosine-1-phosphate and endothelin-1 induce the expression of rgs16 protein in cardiac myocytes by transcriptional activation of the rgs16 gene. Naunyn Schmiedebergs Arch. Pharmacol. 376: 363-73 [PMID:18046543]

478. Su Z, Xu P and Ni F. (2004) Single phosphorylation of Tyr304 in the cytoplasmic tail of ephrin B2 confers high-affinity and bifunctional binding to both the SH2 domain of Grb4 and the PDZ domain of the PDZRGS3 protein. Eur. J. Biochem. 271: 1725-36 [PMID:15096211]

479. Sun H, Calipari ES, Beveridge TJ, Jones SR and Chen R. (2015) The brain gene expression profile of dopamine D2/D3 receptors and associated signaling proteins following amphetamine self-administration. Neuroscience 307: 253-61 [PMID:26321241]

480. Suurväli J, Pahtma M, Saar R, Paalme V, Nutt A, Tiivel T, Saaremäe M, Fitting C, Cavaillon JM and Rüüte Boudinot S. (2015) RGS16 restricts the pro-inflammatory response of monocytes. Scand. J. Immunol. 81: 23-30 [PMID:25366993]

481. Takeishi Y, Jalili T, Hoit BD, Kirkpatrick DL, Wagoner LE, Abraham WT and Walsh RA. (2000) Alterations in $\mathrm{Ca} 2+$ cycling proteins and $\mathrm{G}$ alpha q signaling after left ventricular assist device support in failing human hearts. Cardiovasc. Res. 45: 883-8 [PMID:10728414]

482. Takeuchi T, Inoue S and Yokosawa H. (2006) Identification and Herc5-mediated ISGylation of novel target proteins. Biochem. Biophys. Res. Commun. 348: 473-7 [PMID:16884686]

483. Tamirisa P, Blumer KJ and Muslin AJ. (1999) RGS4 inhibits G-protein signaling in cardiomyocytes. Circulation 99: 441-7 [PMID:9918533]

484. Tang KM, Wang GR, Lu P, Karas RH, Aronovitz M, Heximer SP, Kaltenbronn KM, Blumer KJ, Siderovski DP and Zhu Y et al.. (2003) Regulator of G-protein signaling-2 mediates vascular smooth muscle relaxation and blood pressure. Nat. Med. 9: 1506-12 [PMID:14608379]

485. Taylor VG, Bommarito PA and Tesmer JJ. (2016) Structure of the Regulator of G Protein Signaling 8 (RGS8)-Gaq Complex: MOLECULAR BASIS FOR Ga SELECTIVITY. J. Biol. Chem. 291: 5138-45 [PMID:26755720]

486. Terzi D, Gaspari S, Manouras L, Descalzi G, Mitsi V and Zachariou V. (2014) RGS9-2 modulates sensory and mood related symptoms of neuropathic pain. Neurobiol Learn Mem 115: 43-8 [PMID:25150149]

487. Thomas EA, Danielson PE and Sutcliffe JG. (1998) RGS9: a regulator of G-protein signalling with specific expression in rat and mouse striatum. J. Neurosci. Res. 52: 118-24 [PMID:9556034]

488. Tran T, Paz P, Velichko S, Cifrese J, Belur P, Yamaguchi KD, Ku K, Mirshahpanah P, Reder AT and Croze E. (2010) Interferon $\beta-1 b$ Induces the Expression of RGS1 a Negative Regulator of G-Protein Signaling. Int J Cell Biol 2010: 529376 [PMID:21274427]

489. Traver S, Bidot C, Spassky N, Baltauss T, De Tand MF, Thomas JL, Zalc B, Janoueix-Lerosey I and Gunzburg JD. (2000) RGS14 is a novel Rap effector that preferentially regulates the GTPase activity of galphao. Biochem. J. 350 Pt 1: 19-29 [PMID:10926822]

490. Traver S, Splingard A, Gaudriault G and De Gunzburg J. (2004) The RGS (regulator of G-protein signalling) and GoLoco domains of RGS14 co-operate to regulate Gi-mediated signalling. Biochem. J. 379 : 627-32 [PMID:15112653]

491. Tu Y, Popov S, Slaughter C and Ross EM. (1999) Palmitoylation of a conserved cysteine in the regulator of $G$ protein signaling (RGS) domain modulates the GTPase-activating activity of RGS4 and RGS10. J Biol Chem 274: 38260-7 [PMID:10608901]

492. Tuggle K, Ali MW, Salazar H and Hooks SB. (2014) Regulator of G protein signaling transcript expression in human neural progenitor differentiation: R7 subfamily regulation by DNA methylation. Neurosignals 22: 43-51 [PMID:24903911]

493. Tuomi JM, Chidiac P and Jones DL. (2010) Evidence for enhanced M3 muscarinic receptor function and sensitivity to atrial arrhythmia in the RGS2-deficient mouse. Am. J. Physiol. Heart Circ. Physiol.298: H55461 [PMID:19966055]

494. Turner EM, Blazer LL, Neubig RR and Husbands SM. (2012) Small Molecule Inhibitors of Regulator of G Protein Signalling (RGS) Proteins. ACS Med Chem Lett 3: 146-150 [PMID:22368763]

495. Ueda HR, Chen W, Adachi A, Wakamatsu H, Hayashi S, Takasugi T, Nagano M, Nakahama K, Suzuki Y and Sugano S et al.. (2002) A transcription factor response element for gene expression during circadian 
night. Nature 418: 534-9 [PMID:12152080]

496. Vasilatos SN, Katz TA, Oesterreich S, Wan Y, Davidson NE and Huang Y. (2013) Crosstalk between lysine-specific demethylase 1 (LSD1) and histone deacetylases mediates antineoplastic efficacy of HDAC inhibitors in human breast cancer cells. Carcinogenesis 34: 1196-207 [PMID:23354309]

497. Vatner DE, Zhang J, Oydanich M, Guers J, Katsyuba E, Yan L, Sinclair D, Auwerx J and Vatner SF. (2018) Enhanced longevity and metabolism by brown adipose tissue with disruption of the regulator of $G$ protein signaling 14. Aging Cell 17: e12751 [PMID:29654651]

498. Vellano CP, Brown NE, Blumer JB and Hepler JR. (2013) Assembly and function of the regulator of G protein signaling 14 (RGS14)·H-Ras signaling complex in live cells are regulated by Gai1 and Gai-linked G protein-coupled receptors. J. Biol. Chem. 288: 3620-31 [PMID:23250758]

499. Vellano CP, Maher EM, Hepler JR and Blumer JB. (2011) G protein-coupled receptors and resistance to inhibitors of cholinesterase-8A (Ric-8A) both regulate the regulator of $g$ protein signaling 14 RGS14.Gai1 complex in live cells. J. Biol. Chem. 286: 38659-69 [PMID:21880739]

500. Vellano CP, Shu FJ, Ramineni S, Yates CK, Tall GG and Hepler JR. (2011) Activation of the regulator of G protein signaling 14-Gai1-GDP signaling complex is regulated by resistance to inhibitors of cholinesterase8A. Biochemistry 50: 752-62 [PMID:21158412]

501. Villasenor A, Wang ZV, Rivera LB, Ocal O, Asterholm IW, Scherer PE, Brekken RA, Cleaver O and Wilkie TM. (2010) Rgs16 and Rgs8 in embryonic endocrine pancreas and mouse models of diabetes. Dis Model Mech 3: 567-80 [PMID:20616094]

502. von Buchholtz L, Elischer A, Tareilus E, Gouka R, Kaiser C, Breer H and Conzelmann S. (2004) RGS21 is a novel regulator of $G$ protein signalling selectively expressed in subpopulations of taste bud cells. Eur. J. Neurosci. 19: 1535-44 [PMID:15066150]

503. Wagner SA, Beli P, Weinert BT, Nielsen ML, Cox J, Mann M and Choudhary C. (2011) A proteome-wide, quantitative survey of in vivo ubiquitylation sites reveals widespread regulatory roles. Mol. Cell Proteomics 10: M111.013284 [PMID:21890473]

504. Wang J, Ducret A, Tu Y, Kozasa T, Aebersold R and Ross EM. (1998) RGSZ1, a Gz-selective RGS protein in brain. Structure, membrane association, regulation by Galphaz phosphorylation, and relationship to a Gz gtpase-activating protein subfamily. J. Biol. Chem. 273: 26014-25 [PMID:9748280]

505. Wang J, Lippman SM, Lee JJ, Yang H, Khuri FR, Kim E, Lin J, Chang DW, Lotan R and Hong WKet al.. (2010) Genetic variations in regulator of G-protein signaling genes as susceptibility loci for second primary tumor/recurrence in head and neck squamous cell carcinoma. Carcinogenesis 31: 1755-61 [PMID:20627871]

506. Wang JH, New JS, Xie S, Yang P, Wu Q, Li J, Luo B, Ding Y, Druey KM and Hsu HCet al.. (2013) Extension of the germinal center stage of $B$ cell development promotes autoantibodies in BXD2 mice. Arthritis Rheum. 65: 2703-12 [PMID:23818250]

507. Wang Q, Liu M, Mullah B, Siderovski DP and Neubig RR. (2002) Receptor-selective effects of endogenous RGS3 and RGS5 to regulate mitogen-activated protein kinase activation in rat vascular smooth muscle cells. J. Biol. Chem. 277: 24949-58 [PMID:12006602]

508. Wang X, Zeng W, Soyombo AA, Tang W, Ross EM, Barnes AP, Milgram SL, Penninger JM, Allen PB and Greengard P et al.. (2005) Spinophilin regulates Ca2+ signalling by binding the N-terminal domain of RGS2 and the third intracellular loop of G-protein-coupled receptors. Nat. Cell Biol. 7: 405-11 [PMID:15793568]

509. Wang Y, Ho G, Zhang JJ, Nieuwenhuijsen B, Edris W, Chanda PK and Young KH. (2002) Regulator of G protein signaling Z1 (RGSZ1) interacts with Galpha i subunits and regulates Galpha i-mediated cell signaling. J. Biol. Chem. 277: 48325-32 [PMID:12379657]

510. Wang Y, Wang J, Zhang L, Karatas OF, Shao L, Zhang Y, Castro P, Creighton CJ and Ittmann M. (2017) RGS12 Is a Novel Tumor-Suppressor Gene in African American Prostate Cancer That Represses AKT and MNX1 Expression. Cancer Res 77: 4247-4257 [PMID:28611045]

511. Waugh JL, Lou AC, Eisch AJ, Monteggia LM, Muly EC and Gold SJ. (2005) Regional, cellular, and subcellular localization of RGS10 in rodent brain. J. Comp. Neurol. 481: 299-313 [PMID:15593368]

512. Weinberger MH, Miller JZ, Grim CE, Luft FC, Christian JC and Fineberg NS. (1989) Genetic and environmental approaches to the prevention of hypertension. J Hypertens Supp/ 7: S7-8 [PMID:2709189]

513. White AN, Gross JD, Kaski SW, Trexler KR, Wix KA, Wetsel WC, Kinsey SG, Siderovski DP and Setola V. (2020) Genetic deletion of Rgs12 in mice affects serotonin transporter expression and functionin vivo and ex vivo. J Psychopharmacol 269881120944160 [PMID:32842837]

514. Wiechec E, Overgaard J and Hansen LL. (2008) A fragile site within the HPC1 region at 1q25.3 affecting RGS16, RGSL1, and RGSL2 in human breast carcinomas. Genes Chromosomes Cancer 47: 766-80 [PMID:18521847]

515. Willard FS, Kimple AJ, Johnston CA and Siderovski DP. (2005) A direct fluorescence-based assay for RGS domain GTPase accelerating activity. Anal Biochem 340: 341-51 [PMID:15840508]

516. Willard FS, Willard MD, Kimple AJ, Soundararajan M, Oestreich EA, Li X, Sowa NA, Kimple RJ, Doyle DA and Der CJ et al.. (2009) Regulator of G-protein signaling 14 (RGS14) is a selective H-Ras effector.PLoS ONE 4: e4884 [PMID:19319189]

517. Willard MD, Willard FS, Li X, Cappell SD, Snider WD and Siderovski DP. (2007) Selective role for RGS12 as a Ras/Raf/MEK scaffold in nerve growth factor-mediated differentiation. EMBO J. 26: 2029-40 [PMID:17380122]

518. Willars GB. (2006) Mammalian RGS proteins: multifunctional regulators of cellular signalling.Semin. Cell 
Dev. Biol. 17: 363-76 [PMID:16687250]

519. Williams DS, Bird MJ, Jorissen RN, Yu YL, Walker F, Walker F, Zhang HH, Nice EC and Burgess AW. (2010) Nonsense mediated decay resistant mutations are a source of expressed mutant proteins in colon cancer cell lines with microsatellite instability. PLoS ONE 5: e16012 [PMID:21209843]

520. Williams JW, Yau D, Sethakorn N, Kach J, Reed EB, Moore TV, Cannon J, Jin X, Xing H and Muslin Att al.. (2013) RGS3 controls T lymphocyte migration in a model of Th2-mediated airway inflammation $A m$. J. Physiol. Lung Cell Mol. Physiol. 305: L693-701 [PMID:24077945]

521. Witherow DS, Wang Q, Levay K, Cabrera JL, Chen J, Willars GB and Slepak VZ. (2000) Complexes of the $G$ protein subunit gbeta 5 with the regulators of $G$ protein signaling RGS7 and RGS9. Characterization in native tissues and in transfected cells. J. Biol. Chem. 275: 24872-80 [PMID:10840031]

522. Wong YH, Conklin BR and Bourne HR. (1992) Gz-mediated hormonal inhibition of cyclic AMP accumulation. Science 255: 339-42 [PMID:1347957]

523. Xiao K, McClatchy DB, Shukla AK, Zhao Y, Chen M, Shenoy SK, Yates 3rd JR and Lefkowitz RJ. (2007) Functional specialization of beta-arrestin interactions revealed by proteomic analysis. Proc. Natl. Acad. Sci. U.S.A. 104: 12011-6 [PMID:17620599]

524. Xie K, Allen KL, Kourrich S, Colón-Saez J, Thomas MJ, Wickman K and Martemyanov KA. (2010) Gbeta5 recruits R7 RGS proteins to GIRK channels to regulate the timing of neuronal inhibitory signaling. Nat. Neurosci. 13: 661-3 [PMID:20453851]

525. Xie K, Masuho I, Brand C, Dessauer CW and Martemyanov KA. (2012) The complex of G protein regulator RGS9-2 and GB(5) controls sensitization and signaling kinetics of type 5 adenylyl cyclase in the striatum. Sci Signal 5: ra63 [PMID:22932702]

526. Xie S, Li J, Wang JH, Wu Q, Yang P, Hsu HC, Smythies LE and Mountz JD. (2010) IL-17 activates the canonical NF-kappaB signaling pathway in autoimmune B cells of BXD2 mice to upregulate the expression of regulators of G-protein signaling 16. J. Immunol. 184: 2289-96 [PMID:20139273]

527. Xie Y, Jiang H, Nguyen H, Jia S, Berro A, Panettieri Jr RA, Wolff DW, Abel PW, Casale TB and Tu Y. (2012) Regulator of $G$ protein signaling 2 is a key modulator of airway hyperresponsiveness. J. Allergy Clin. Immunol. 130: 968-76.e3 [PMID:22704538]

528. Xie Y, Wolff DW, Wei T, Wang B, Deng C, Kirui JK, Jiang H, Qin J, Abel PW and Tu Y. (2009) Breast cancer migration and invasion depend on proteasome degradation of regulator of G-protein signaling 4. Cancer Res. 69: 5743-51 [PMID:19549919]

529. Xie Z, Geiger TR, Johnson EN, Nyborg JK and Druey KM. (2008) RGS13 acts as a nuclear repressor of CREB. Mol. Cell 31: 660-70 [PMID:18775326]

530. Xu Z, Zuo Y, Wang J, Yu Z, Peng F, Chen Y, Dong Y, Hu X, Zhou Q and Ma łet al.. (2015) Overexpression of the regulator of $G$-protein signaling 5 reduces the survival rate and enhances the radiation response of human lung cancer cells. Oncol. Rep. 33: 2899-907 [PMID:25891540]

531. Yan J, Takahashi T, Ohura T, Adachi H, Takahashi I, Ogawa E, Okuda H, Kobayashi H, Hitomi T and Liu W et al.. (2013) Combined linkage analysis and exome sequencing identifies novel genes for familial goiter. J. Hum. Genet. 58: 366-77 [PMID:23535966]

532. Yang J, Huang J, Maity B, Gao Z, Lorca RA, Gudmundsson H, Li J, Stewart A, Swaminathan PD and Ibeawuchi SR et al.. (2010) RGS6, a modulator of parasympathetic activation in heart.Circ. Res. 107: 1345-9 [PMID:20864673]

533. Yang J, Kamide K, Kokubo Y, Takiuchi S, Tanaka C, Banno M, Miwa Y, Yoshii M, Horio T and Okayama A et al.. (2005) Genetic variations of regulator of G-protein signaling 2 in hypertensive patients and in the general population. J. Hypertens. 23: 1497-505 [PMID:16003176]

534. Yang J, Maity B, Huang J, Gao Z, Stewart A, Weiss RM, Anderson ME and Fisher RA. (2013) G-protein inactivator RGS6 mediates myocardial cell apoptosis and cardiomyopathy caused by doxorubicin. Cancer Res. 73: 1662-7 [PMID:23338613]

535. Yang J, Platt LT, Maity B, Ahlers KE, Luo Z, Lin Z, Chakravarti B, Ibeawuchi SR, Askeland RW and Bondaruk J et al.. (2016) RGS6 is an essential tumor suppressor that prevents bladder carcinogenesis by promoting p53 activation and DNMT1 downregulation. Oncotarget 7: 69159-69172 [PMID:27713144]

536. Yang S, Chen W, Stashenko P and Li YP. (2007) Specificity of RGS10A as a key component in the RANKL signaling mechanism for osteoclast differentiation. J. Cell. Sci. 120: 3362-71 [PMID:17881498]

537. Yang S, Hao L, McConnell M, Zhou X, Wang M, Zhang Y, Mountz JD, Reddy M, Eleazer PD and Li YRet al.. (2013) Inhibition of Rgs10 Expression Prevents Immune Cell Infiltration in Bacteria-induced Inflammatory Lesions and Osteoclast-mediated Bone Destruction. Bone Res 1: 267-281 [PMID:24761229]

538. Yang S and Li YP. (2007) RGS10-null mutation impairs osteoclast differentiation resulting from the loss of [Ca2+]i oscillation regulation. Genes Dev. 21: 1803-16 [PMID:17626792]

539. Yang S and Li YP. (2007) RGS12 is essential for RANKL-evoked signaling for terminal differentiation of osteoclasts in vitro. J. Bone Miner. Res. 22: 45-54 [PMID:17042716]

540. Yang S, Li YP, Liu T, He X, Yuan X, Li C, Cao J and Kim Y. (2013) Mx1-cre mediated Rgs12 conditional knockout mice exhibit increased bone mass phenotype. Genesis 51: 201-9 [PMID:23349096]

541. Yang SH, Li CF, Chu PY, Ko HH, Chen LT, Chen WW, Han CH, Lung JH and Shih NY. (2016) Overexpression of regulator of $\mathrm{G}$ protein signaling 11 promotes cell migration and associates with advanced stages and aggressiveness of lung adenocarcinoma. Oncotarget 7: 31122-36 [PMID:27105500]

542. Yang Z, Balenga N, Cooper PR, Damera G, Edwards R, Brightling CE, Panettieri Jr RA and Druey KM. (2012) Regulator of G-protein signaling-5 inhibits bronchial smooth muscle contraction in severe asthma. Am. J. Respir. Cell Mol. Biol. 46: 823-32 [PMID:22281988]

543. Yang Z, Cooper PR, Damera G, Mukhopadhyay I, Cho H, Kehrl JH, Panettieri Jr RA and Druey KM. (2011) 
Beta-agonist-associated reduction in RGS5 expression promotes airway smooth muscle hyperresponsiveness. J. Biol. Chem. 286: 11444-55 [PMID:21278382]

544. Yang Z, Gaudio S, Song W, Greenwood M, Jean-Baptiste G and Greenwood MT. (2007) Evidence for the dimerization of human regulator of G-protein signalling 5 (RGS5). Cell. Physiol. Biochem. 20: 303-10 [PMID:17762159]

545. Yen WC, Fischer MM, Axelrod F, Bond C, Cain J, Cancilla B, Henner WR, Meisner R, Sato A and Shah J et al.. (2015) Targeting Notch signaling with a Notch2/Notch3 antagonist (tarextumab) inhibits tumor growth and decreases tumor-initiating cell frequency. Clin. Cancer Res. 21: 2084-95 [PMID:25934888]

546. Yono M, Yoshida M, Yamamoto Y, Imanishi A, Fukagawa A, Latifpour J and Eto M. (2010) Identification of potential therapeutic targets in hypertension-associated bladder dysfunction. BJU Int. 105: 877-83 [PMID:19689474]

547. Yowe D, Weich N, Prabhudas M, Poisson L, Errada P, Kapeller R, Yu K, Faron L, Shen M and Cleary et al.. (2001) RGS18 is a myeloerythroid lineage-specific regulator of G-protein-signalling molecule highly expressed in megakaryocytes. Biochem. J. 359: 109-18 [PMID:11563974]

548. Yuan G, Yang S, Liu M and Yang S. (2020) RGS12 is required for the maintenance of mitochondrial function during skeletal development. Cell Discov 6: 59 [PMID:32922858]

549. Yuan G, Yang S, Ng A, Fu C, Oursler MJ, Xing L and Yang S. (2020) RGS12 Is a Novel Critical NF-kB Activator in Inflammatory Arthritis. iScience 23: 101172 [PMID:32512384]

550. Yuan X, Cao J, Liu T, Li YP, Scannapieco F, He X, Oursler MJ, Zhang X, Vacher J and Li @t al.. (2015) Regulators of $\mathrm{G}$ protein signaling 12 promotes osteoclastogenesis in bone remodeling and pathological bone loss. Cell Death Differ. 22: 2046-57 [PMID:25909889]

551. Zachariou V, Georgescu D, Sanchez N, Rahman Z, DiLeone R, Berton O, Neve RL, Sim-Selley LJ, Selley DE and Gold SJ et al.. (2003) Essential role for RGS9 in opiate action. Proc. Natl. Acad. Sci. U.S.A. 100: 13656-61 [PMID:14595021]

552. Zarzuelo MJ, Gómez-Guzmán M, Jiménez R, Quintela AM, Romero M, Sánchez M, Zarzuelo A, Tamargo J, Pérez-Vizcaíno F and Duarte J. (2013) Effects of peroxisome proliferator-activated receptor- $\beta$ activation in endothelin-dependent hypertension. Cardiovasc. Res. 99: 622-31 [PMID:23752977]

553. Zarzuelo MJ, Jiménez R, Galindo P, Sánchez M, Nieto A, Romero M, Quintela AM, López-Sepúlveda R, Gómez-Guzmán M and Bailón E et al.. (2011) Antihypertensive effects of peroxisome proliferator-activated receptor- $\beta$ activation in spontaneously hypertensive rats. Hypertension 58: 733-43 [PMID:21825230]

554. Zhang D, Pang Z, Li S, Jiang W, Wang S, Thomassen M, Hjelmborg JV, Kruse TA, Ohm Kyvik K and Christensen $\mathrm{K}$ et al.. (2012) Genome-wide linkage and association scans for pulse pressure in Chinese twins. Hypertens. Res. 35: 1051-7 [PMID:22763476]

555. Zhang H, Gu S, Al-Sabeq B, Wang S, He J, Tam A, Cifelli C, Mathalone N, Tirgari S and Boyd Set al.. (2012) Origin-specific epigenetic program correlates with vascular bed-specific differences in Rgs5 expression. FASEB J. 26: 181-91 [PMID:21965603]

556. Zhang J, Jeffrey BG, Morgans CW, Burke NS, Haley TL, Duvoisin RM and Brown RL. (2010) RGS7 and 11 complexes accelerate the ON-bipolar cell light response. Invest. Ophthalmol. Vis. Sci. 51: 1121-9 [PMID:19797214]

557. Zhang K, Howes KA, He W, Bronson JD, Pettenati MJ, Chen C, Palczewski K, Wensel TG and Baehr W. (1999) Structure, alternative splicing, and expression of the human RGS9 gene. Gene 240: 23-34 [PMID:10564809]

558. Zhang $P$ and Mende U. (2011) Regulators of G-protein signaling in the heart and their potential as therapeutic targets. Circ. Res. 109: 320-33 [PMID:21778436]

559. Zhang S, Watson N, Zahner J, Rottman JN, Blumer KJ and Muslin AJ. (1998) RGS3 and RGS4 are GTPase activating proteins in the heart. J. Mol. Cell. Cardiol. 30: 269-76 [PMID:9515003]

560. Zhang W, Anger T, Su J, Hao J, Xu X, Zhu M, Gach A, Cui L, Liao R and Mende U. (2006) Selective loss of fine tuning of $\mathrm{Gq} / 11$ signaling by RGS2 protein exacerbates cardiomyocyte hypertrophy. J. Biol. Chem. 281: 5811-20 [PMID:16380388]

561. Zhang Y, Zhang C, Li H and Hou J. (2019) The Presence of High Levels of Circulating Trimethylamine NOxide Exacerbates Central and Peripheral Inflammation and Inflammatory Hyperalgesia in Rats Following Carrageenan Injection. Inflammation 42: 2257-2266 [PMID:31489527]

562. Zhao P and Chidiac P. (2015) Regulation of RGS5 GAP activity by GPSM3.Mol. Cell. Biochem. 405: 3340 [PMID:25842189]

563. Zhao P, Nunn C, Ramineni S, Hepler JR and Chidiac P. (2013) The Ras-binding domain region of RGS14 regulates its functional interactions with heterotrimeric $G$ proteins. J. Cell. Biochem. 114: 1414-23 [PMID:23255434]

564. Zheng B, Berrie CP, Corda D and Farquhar MG. (2003) GDE1/MIR16 is a glycerophosphoinositol phosphodiesterase regulated by stimulation of $\mathrm{G}$ protein-coupled receptors. Proc. Natl. Acad. Sci. U.S.A. 100: 1745-50 [PMID:12576545]

565. Zheng B, Chen D and Farquhar MG. (2000) MIR16, a putative membrane glycerophosphodiester phosphodiesterase, interacts with RGS16. Proc. Natl. Acad. Sci. U.S.A. 97: 3999-4004 [PMID:10760272]

566. Zhong H and Neubig RR. (2001) Regulator of G protein signaling proteins: novel multifunctional drug targets. J. Pharmacol. Exp. Ther. 297: 837-45 [PMID:11356902]

567. Zhou J, Moroi K, Nishiyama M, Usui H, Seki N, Ishida J, Fukamizu A and Kimura S. (2001) Characterization of RGS5 in regulation of G protein-coupled receptor signaling. Life Sci. 68: 1457-69 [PMID:11253162] 
568. Zielinski T, Kimple AJ, Hutsell SQ, Koeff MD, Siderovski DP and Lowery RG. (2009) Two Galpha(i1) ratemodifying mutations act in concert to allow receptor-independent, steady-state measurements of RGS protein activity. J Biomol Screen 14: 1195-206 [PMID:19820068] 